\title{
Hydrogeologic Framework of Mississippian Rocks in the Central Lower Peninsula of Michigan
}

By D.B. WESTJOHN and T.L. WEAVER

U.S. Geological Survey

Water-Resources Investigations Report 94-4246

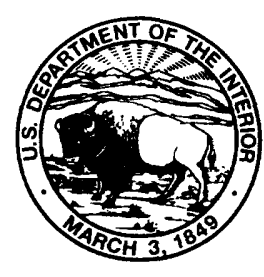

Lansing, Michigan

1996 


\title{
U.S. DEPARTMENT OF THE INTERIOR \\ BRUCE BABBITT, Secretary
}

\author{
U.S. GEOLOGICAL SURVEY \\ Gordon P. Eaton, Director
}

\begin{abstract}
Any use of trade, product, or firm name in this report is for identification purposes only and does not constitute endorsement by the U.S.

Geological Survey.
\end{abstract}

For additional information write to:

District Chief

U.S. Geological Survey, WRD 6520 Mercantile Way, Suite 5 Lansing, MI 48911
Copies of this report may be purchased from:

U.S. Geological Survey Earth Science Information Center Open-File Reports Section Box 25286, MS 517

Denver Federal Center

Denver, CO 80225 


\section{CONTENTS}

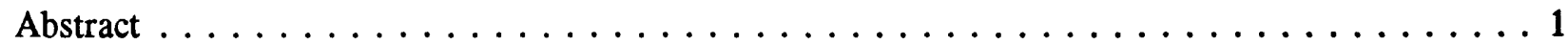

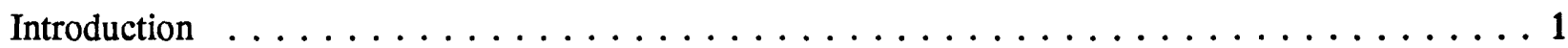

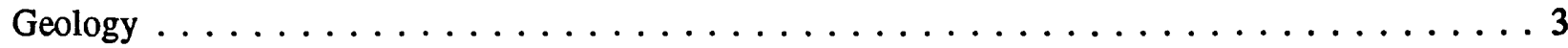

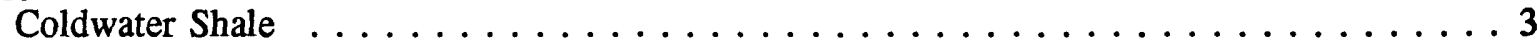

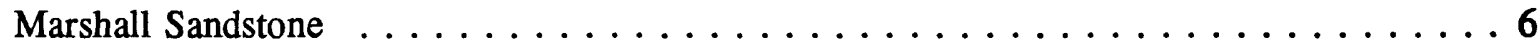

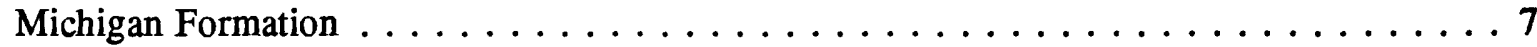

Hydrogeologic framework of Mississippian rocks $\ldots \ldots \ldots \ldots \ldots \ldots \ldots \ldots \ldots$

Relations of stratigraphic units to aquifer and confining units $\ldots \ldots \ldots \ldots \ldots$

Delineation of aquifer- and confining-unit boundaries $\ldots \ldots \ldots \ldots \ldots$

Description of confining units and the Marshall aquifer $\ldots \ldots \ldots \ldots \ldots$. . . .

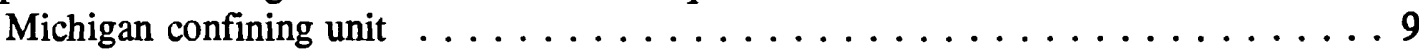

Areal extent, surface configuration, and thickness $\ldots \ldots \ldots \ldots \ldots \ldots$

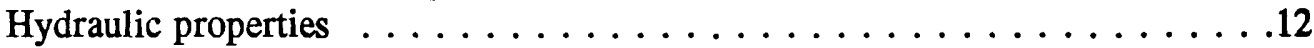

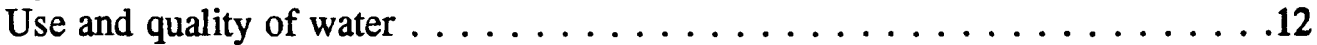

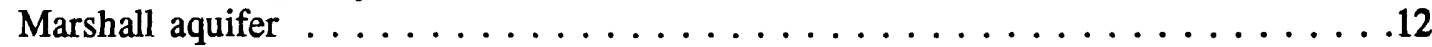

Areal extent, surface configuration, and thickness $\ldots \ldots \ldots \ldots \ldots \ldots 12$

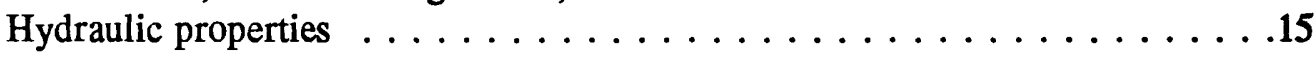

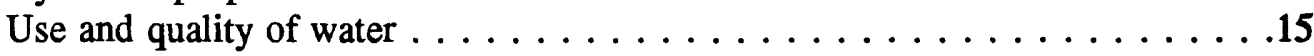

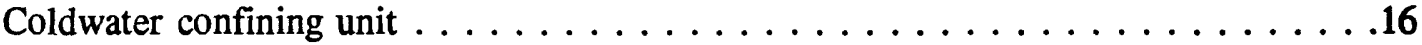

Areal extent and surface configuration $\ldots \ldots \ldots \ldots \ldots \ldots \ldots \ldots$

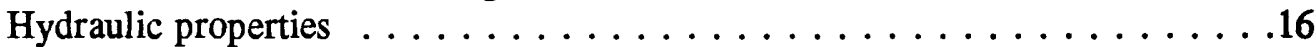

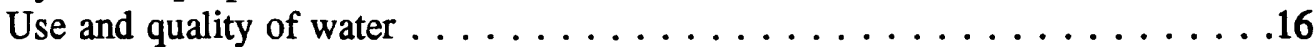

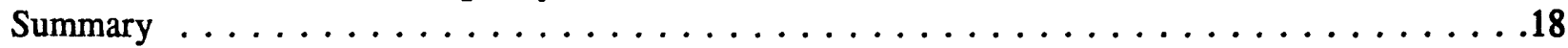

References cited . . . . . . . . . . . . . . . . . . . . . . . . . . . . 19

Appendix A: Identification and locations of geophysical and geologic logs, and generalized

hydrogeologic sections illustrating relations of aquifers and confining units $\ldots \ldots .25$

Appendix B: Interpretation of geophysical and geologic $\operatorname{logs} \ldots \ldots \ldots \ldots \ldots \ldots \ldots \ldots$

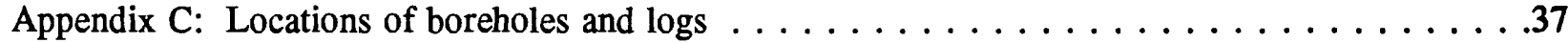

Appendix D: Hydraulic properties of Mississippian sandstones $\ldots \ldots \ldots \ldots \ldots \ldots \ldots .43$ 


\section{FIGURES}

1. Map showing Lower Peninsula of Michigan and Michigan Basin

Regional Aquifer-System Analysis study area . . . . . . . . . . . . . . 2

2. Map showing bedrock geology of the Lower Peninsula of Michigan . . . . . . . . . . . . 4

3. Chart showing Mississippian through Pleistocene stratigraphic nomenclature,

hydrogeologic units, and rock units in the central Lower Peninsula of Michigan . . . . 5 5

4-8. Maps showing:

4. Surface configuration of Michigan confining unit in the central Lower

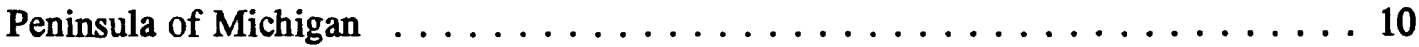

5. Thickness of Michigan confining unit in the central Lower Peninsula of Michigan . . 11

6. Surface configuration of Marshall aquifer in the central Lower Peninsula

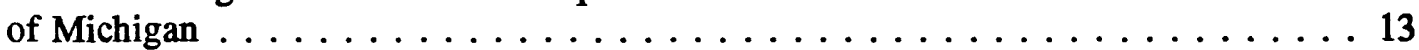

7. Thickness of Marshall aquifer in the central Lower Peninsula of Michigan . . . . . . 14

8. Surface configuration of Coldwater confining unit in the central Lower

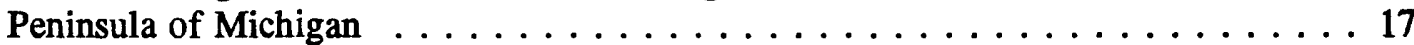

\section{CONVERSION FACTORS, VERTICAL DATUM, AND ABBREVIATED WATER-QUALITY UNITS}

\begin{tabular}{|c|c|c|}
\hline Multiply & By & To obtain \\
\hline foot $(\mathrm{ft})$ & 0.3048 & meter \\
\hline foot (ft) & 30.48 & centimeter \\
\hline mile (mi) & 1.609 & kilometer \\
\hline square mile $\left(\mathrm{mi}^{2}\right)$ & 2.590 & square kilometer \\
\hline gallon (gal) & 0.1337 & cubic foot \\
\hline gallon (gal) & 0.003785 & cubic meter \\
\hline foot per day $1 \mathrm{ft} / \mathrm{d})$ & 0.0003528 & centimeter per second \\
\hline foot squared per $\mathrm{day}^{2}\left(\mathrm{ft}^{2} / \mathrm{d}\right)$ & 0.0009299 & meter squared per day \\
\hline gallon per day per foot $[(\mathrm{gal} / \mathrm{d}) / \mathrm{ft}]$ & 0.01242 & meter squared per day \\
\hline million gallons per day (Mgal/day) & 3,785 & cubic meter per day \\
\hline
\end{tabular}

Sea level: In this report "sea level" refers to the National Geodetic Vertical Datum of 1929 (NGVD of 1929) -a geodetic datum derived from a general adjustment of the first-order level nets of both the United States and Canada, formerly called Sea Level Datum of 1929.

Abbreviated water-quality units used in this report: Chemical concentration is given in milligrams per liter (mg/L) or micrograms per liter $(\mu / \mathrm{L})$. Milligrams per liter is a unit expressing the concentration of chemical constituents in solution as weight (milligrams) of solute per unit volume (liter) of water. One thousand micrograms per liter is equivalent to one milligram per liter. For concentrations less than $7,000 \mathrm{mg} / \mathrm{L}$, the numerical value is the same as for concentrations in parts per million.

\footnotetext{
${ }^{1}$ Hydraulic conductivity by definition is given in units of cubic feet per day per square foot $\left[\left(\mathrm{ft}^{3} / \mathrm{d}\right) / \mathrm{ft}^{2}\right]$, which is mathematically equivalent to feet per day ( $\mathrm{t} / \mathrm{d})$.

${ }^{2}$ Transmissivity by definition is given in units of cubic feet per day per foot $\left[\left(\mathrm{f}^{3} / \mathrm{d}\right) / \mathrm{ft}\right]$, which is mathematically equivalent to square feet per day $\left(\mathrm{ft}^{2} / \mathrm{d}\right)$.
}

Other abbreviations used in this report:

$(\mathrm{cm} / \mathrm{s})$ centimeters per second

(Kv) vertical hydraulic conductivity

(Kh) horizontal hydraulic conductivity 


\title{
Hydrogeologic Framework of Mississippian Rocks in the Central Lower Peninsula of Michigan
}

\author{
By D.B. Westjohn and T.L. Weaver
}

\section{Abstract}

Sedimentary rocks of Mississippian age form the lower part of a regional aquifer system in the central Lower Peninsula of Michigan. Strata of the Michigan Formation, the Marshall Sandstone, and the Coldwater Shale were subdivided into an aquifer and two confining units on the basis of hydraulic properties. The Michigan confining unit consists of shale, limestone, dolomite, gypsum, anhydrite, and discontinuous beds of sandstone and siltstone. The areal extent of this unit is approximately 17,000 square miles, and thickness typically ranges from 300 to 400 feet. The Michigan confining unit overlies the Marshall aquifer. This aquifer consists of one or more stratigraphically continuous, permeable sandstones, which are hydraulically connected at the scale of the regional aquifer system. The areal extent of this regional aquifer is approximately 22,000 square miles, and the composite thickness of permeable sandstones that form the Marshall aquifer typically ranges from $\mathbf{7 5}$ to $\mathbf{1 7 5}$ feet. The Marshall aquifer is freshwater bearing in areas where it is in direct hydraulic connection to Pleistocene glacial deposits. Saline water is present in this aquifer in a zone of transition from freshwater to brine. The width of this transition zone typically ranges from 10 to 30 miles, but width is as narrow as 2 to 4 miles in the northern part of the aquifer system. The Marshall aquifer contains brine in the central part of the basin (areal extent approximately 10,000 square miles), where it is more than 800 feet below land surface. The Coldwater confining unit, which underlies the Marshall aquifer, ranges from 500 to 1,300 feet in thickness. This confining unit forms the basal part of the regional aquifer system, and it consists mostly of shale.

\section{INTRODUCTION}

Bedrock units of Mississippian through Jurassic age and unconsolidated Pleistocene glacial deposits form a regional system of aquifers and confining units in the central Lower Peninsula of Michigan. The areal extent of this aquifer system is approximately $22,000 \mathrm{mi}^{2}$ (fig. 1). This aquifer system was studied during the period from 1986 through 1994 as part of the Regional Aquifer-System Analysis (RASA) program (Mandle, 1986) of the U.S. Geological Survey (USGS). The Michigan Basin RASA project is one of 28 USGS hydrogeologic investigations of regional aquifer systems of the United States (Weeks and Sun, 1987).

The purposes of this report are to describe the hydrogeology and hydraulic properties of geologic units of Mississippian age in the Michigan Basin, and to publish maps that delineate surface configuration and thickness of aquifer-system units. Descriptions of hydrogeologic units are summarized on the basis of published information and data collected as part of the Michigan Basin RASA 


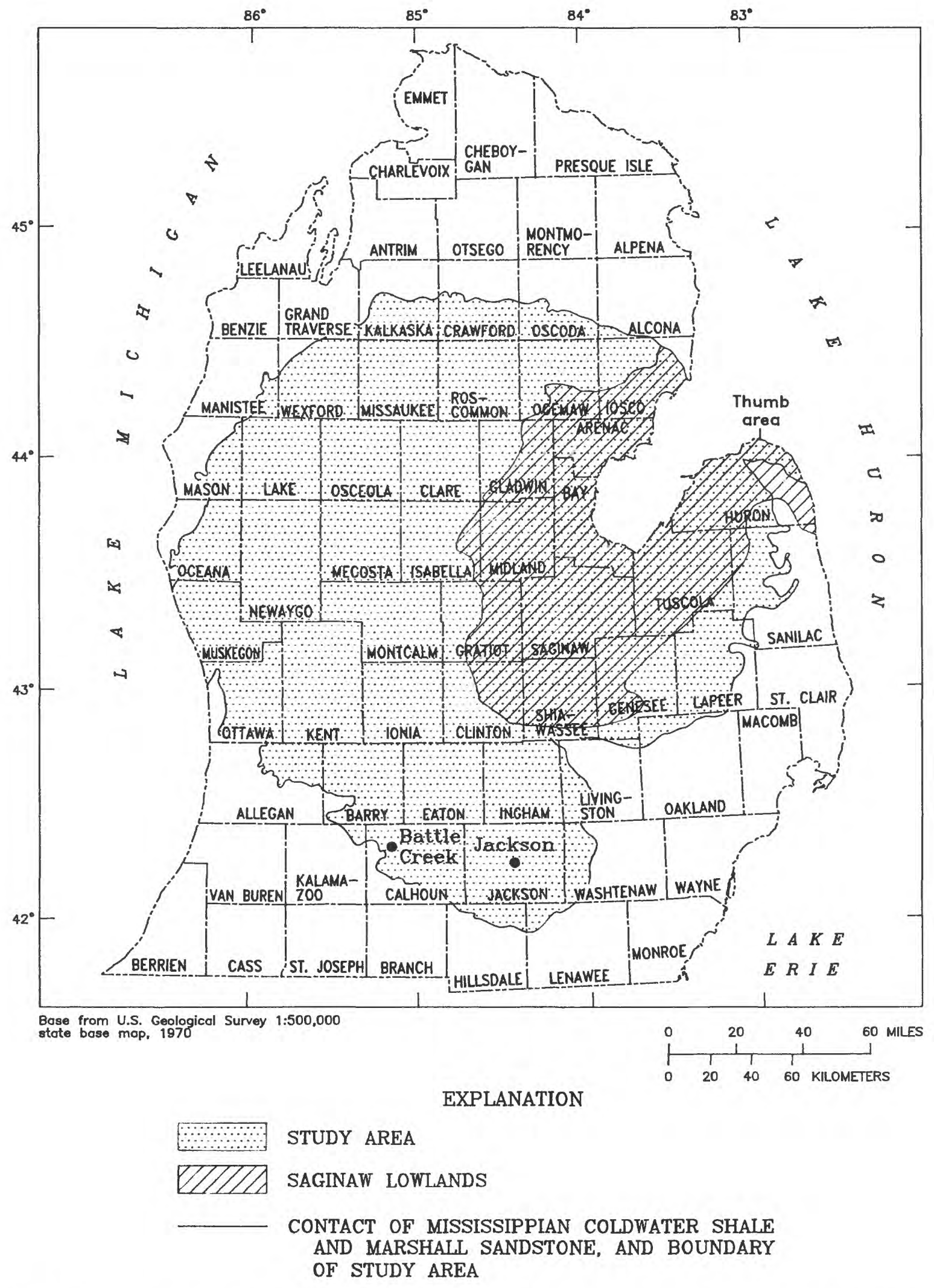

Figure 1. Lower Peninsula of Michigan and Michigan Basin Regional Aquifer-System Analysis study area. 
investigation. Maps that delineate aquifer- and confining-unit boundaries were prepared by use of geophysical and geologic logs of oil, gas, and water wells.

\section{GEOLOGY}

The Michigan Basin is an intracratonic depression that contains more than $17,000 \mathrm{ft}$ of sedimentary rocks and unconsolidated sediments. The stratigraphic record is nearly complete from sedimentary rocks of Precambrian age at the base of the stratigraphic sequence through Jurassic red beds, with the exception that rocks of Triassic age are not present in the basin. Because Pleistocene glacial deposits cover bedrock in most areas, knowledge of bedrock geology is almost entirely from geophysical and geologic logs of drill holes.

Geologic units that form the Michigan Basin regional aquifer system are Early Mississippian through Jurassic age bedrock units, and unconsolidated glacial deposits of Pleistocene age. The aquifer system consists of six formations that have formal stratigraphic names and three geologic units that have informal names (figs. 2 and 3). Formally named units of Mississippian age are the Coldwater Shale, the Marshall Sandstone, the Michigan Formation, and the Bayport Limestone. Formally named units of Pennsylvanian age are the Saginaw Formation and the Grand River Formation. Geologic units that have informal names are the Parma sandstone (member of the Saginaw Formation), Jurassic red beds and Pleistocene glacial deposits.

Reports by Westjohn and Weaver $(1994,1996 a)$ and Westjohn and others (1994) provide geologic descriptions and contain bibliographies of geological investigations of Late Mississippian and all younger geologic units, which form the upper part of the regional aquifer system. The geologic setting, stratigraphic relations, and hydrogeologic framework of the Coldwater Shale, Marshall Sandstone, and Michigan Formation, which form the lower part of the aquifer system, are described in this report. The stratigraphic relations of Mississippian bedrock units and overlying geologic deposits are shown in generalized hydrogeologic sections $\mathrm{A}-\mathrm{A}^{\prime}$ and $\mathrm{B}-\mathrm{B}^{\prime}$ (Appendix A).

\section{Coldwater Shale}

The Coldwater Shale is primarily gray to dark gray shale. Other lithologies include red fossiliferous or nonfossiliferous shale (informally called Coldwater red rock; see Michigan Geological Survey, 1964), carbonate (limestone or dolomite, particularly in the western half of the basin), siltstone, and sandstone. In the northeastern part of the basin, natural-gas-bearing sandstones in the Coldwater Shale have been informally named the Weir sand (Michigan Geological Survey, 1964).

The source area for the Coldwater Shale and overlying clastic sedimentary rocks of Mississippian age is inferred to be in southeastern Ontario (Potter and Pryor, 1961). In the Thumb Area (fig. 1), which is near the inferred sediment source, the upper part of the Coldwater Shale consists of intercalated shale, siltstone, and sandstone. The Coldwater sequence in this area is interpreted to be part of a southwest-prograded-deltaic complex. Cumulative thickness of sandstone beds in the Coldwater Shale ranges from 100 to $200 \mathrm{ft}$ in the Thumb Area (fig. 1), but sandstone beds thin to the southwest and are absent in most of the western part of the Lower Peninsula (Cohee, 1979, p. 54). Total thickness of the Coldwater Shale ranges from $500 \mathrm{ft}$ in the west (Cohee, 1979) to more than $1,300 \mathrm{ft}$ in the east (John Esch, Michigan Department of Natural Resources, written commun., 1994).

Topics of previous investigations of the Coldwater Shale have included economic geology (Cohee and others, 1951; Newcombe, 1933), general geology (Dorr and Eschman, 1970; Ells, 1979; 


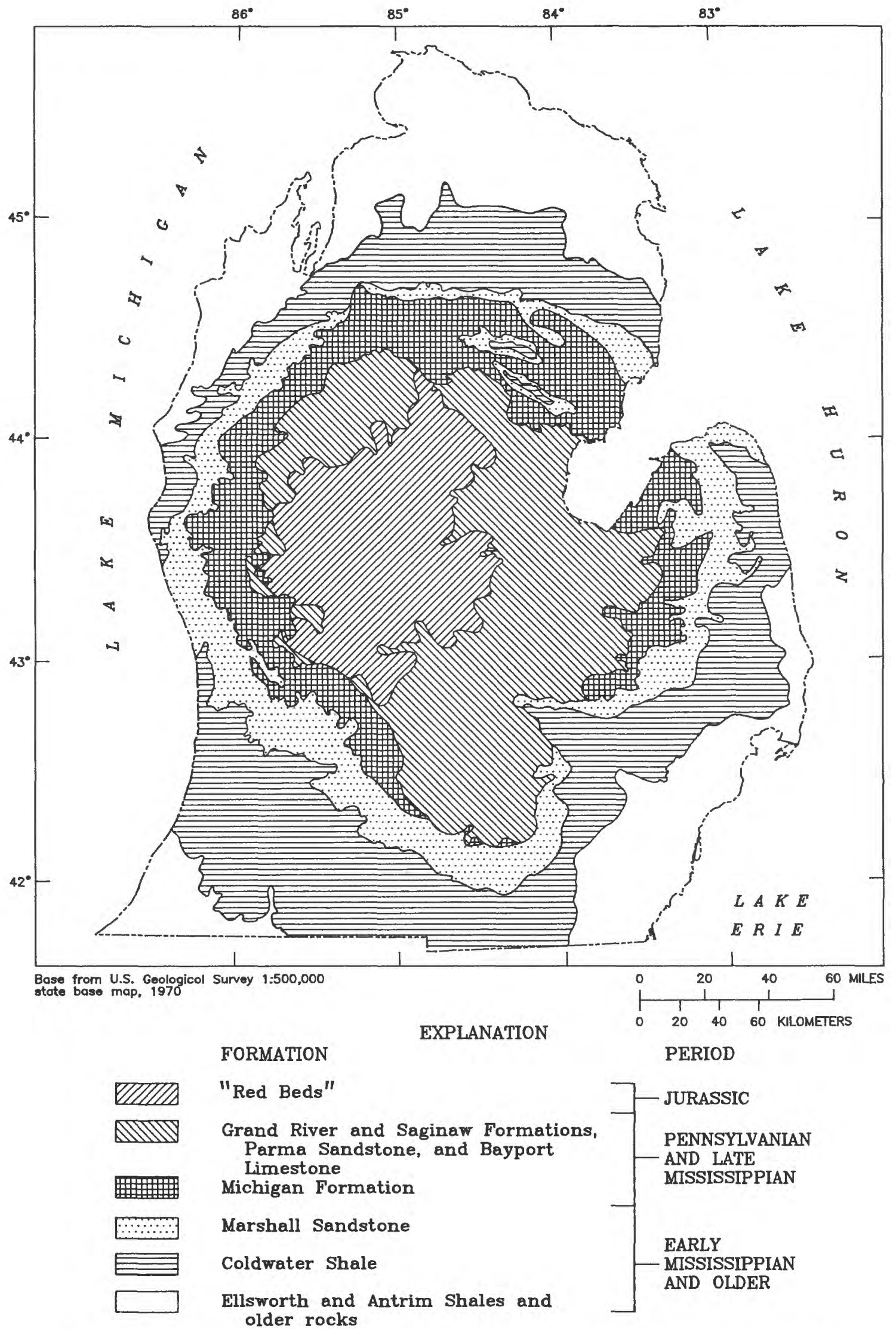

Figure 2. Bedrock geology of the Lower Peninsula of Michigan. (Modified from Western Michigan University, 1981, pl. 12; and from Westjohn and others, 1994.) 


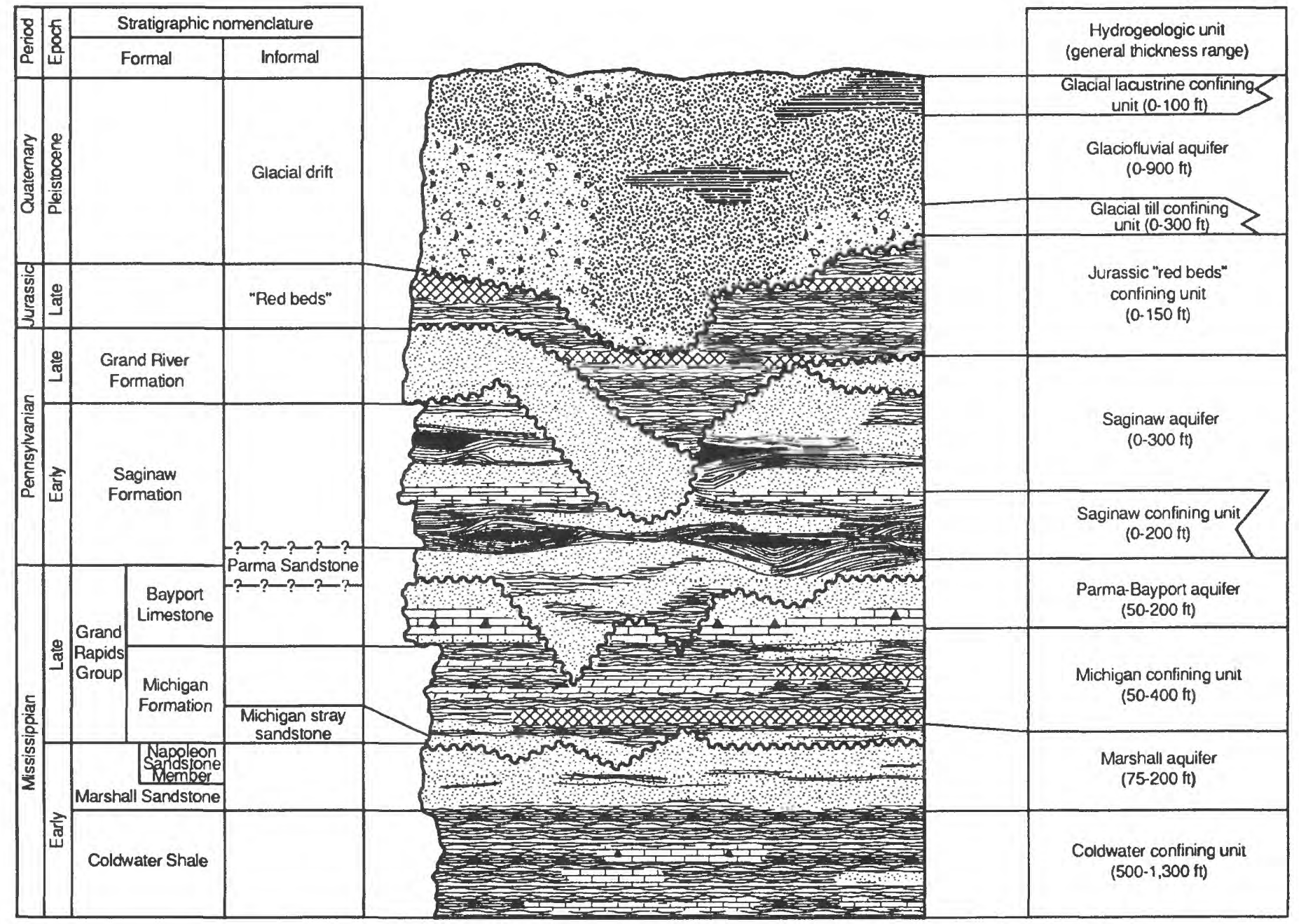

\section{EXPLANATION}

$\begin{array}{ll}\text { Glacial lacustrine sediments } & \text { Claciofluvial sand and gravel } \\ \text { (Same variations as limestone) }\end{array}$

Figure 3. Mississippian through Pleistocene stratigraphic nomenclature, hydrogeologic units, and rock units in the central Lower Peninsula of Michigan. (Modified from Michigan Geological Survey, 1964.) 
Wooten, 1951), hydrogeology (Mandle and Westjohn, 1989; Westjohn and Weaver, 1994), paleontology (Driscoll, 1969), paleotectonic setting (Cohee, 1979), palynology (See, 1980), and sedimentology and stratigraphy (Chung, 1973; Harrell and others, 1991; Kropschot, 1953; Lilienthal, 1978; Potter and Pryor, 1961; Shaver, 1985; Tarbell, 1941). Martin and Straight (1956) provide a bibliography of early investigations and a historic account of development of stratigraphic nomenclature for the Coldwater Shale.

\section{Marshall Sandstone}

The Marshall Sandstone is the formal stratigraphic name for a sequence of sedimentary rocks between the Coldwater Shale and the Michigan Formation (fig. 3). Sandstone constitutes only part of the formation. Limestone, dolomite, siltstone, and shale are interbedded with sandstones of the Marshall sedimentary sequence in different parts of the basin. Two relatively thick, stratigraphically continuous sandstones constitute most of the Marshall Sandstone (formation name) in most areas. The upper sandstone is formally named the Napoleon Sandstone Member. However, use of this formal name is somewhat obscure, because other strata of the Marshall sedimentary sequence have not been formally named (hence, the Marshall Sandstone with formation rank has only one member). Typically, when the Marshall Sandstone is subdivided, the informal stratigraphic term "lower Marshall sandstone" and the formal name Napoleon Sandstone (also commonly called the upper Marshall sandstone) are used to identify sandstones that are separated by other lithologies. These formal and informal names are used in this report where stratigraphic relations of different sandstone units are the topic of discussion.

Examination of geophysical logs shows that lithofacies trends of strata are mappable within the Marshall Sandstone. A description of the vertical and lateral lithofacies trends, which is useful in characterization of hydrogeology of Mississippian rock units (see later section) is given on the basis of interpretation of geophysical logs.

Everywhere in the Michigan Basin where the Marshall Sandstone is present, the basal part of the formation consists of 30 to $125 \mathrm{ft}$ of fine-grained micaceous sandstone or micaceous siltstone. This basal unit of the Marshall sequence has a distinctive shaly-sand trace (Asquith and Gibson, 1982, p. 31 and p. 102) on gamma-ray and spontaneous potential geophysical logs (Appendix B).

The basal micaceous sandstone/siltstone of the Marshall sequence is overlain by fine- to mediumgrained sandstone, which is typically 50 to $125 \mathrm{ft}$ thick. This fine- to medium-grained sandstone is referred to as the "lower Marshall sandstone" by geologists that divide the formation into members (Ells, 1979; Harrell and others, 1991; Martin, 1936). In some areas of the basin, these two units constitute the entire formation.

In areas where a second sandstone is present and is considered to be part of the Marshall sedimentary sequence, this sandstone is commonly called the "Napoleon Sandstone Member" (Harrell and others, 1991; Martin, 1936; Michigan Geological Survey, 1964). The Napoleon Sandstone has the same range of thickness as the lower Marshall sandstone, and it is not possible to differentiate these sandstones on the basis of lithologic characteristics (Monnett, 1948).

Generally, where the lower sandstone is thick, the upper sandstone is thin, and vice versa. Lower and upper sandstones are separated by strata whose facies relations are complex. In some areas, particularly along a 15-mi-wide corridor (extending northwest) from Livingston County to Newaygo County (fig. 1), the lower sandstone is overlain by 15 or more $\mathrm{ft}$ of shale, and this shale is overlain by 30 or more $\mathrm{ft}$ of siltstone (see example log, Appendix B). On either side of this corridor, an intercalated sequence of carbonate, siltstone, and shale, and (or) evaporite separates the upper 
sandstone from the lower sandstone. Strata between these sandstones interfinger, and they seem to be facies assemblages of time-stratigraphic equivalents, which were deposited in sub-basins that developed during late Marshall sedimentation.

Topics of previous investigations of Mississippian sandstones in the Michigan Basin have included economic geology (Ball and others, 1941; Cohee and others, 1951; Hake, 1938; Hale, 1941; Hard, 1938; Harrell and others, 1991; Newcombe, 1933), general geology (Dorr and Eschman, 1970; Ells, 1979), hydrogeology (Mandle and Westjohn, 1989; Westjohn and Weaver, 1994), mineralogy and petrology (Stearns, 1933; Stearns and Cook, 1931; Zacharias and others, 1994), paleotectonic setting (Cohee, 1979), paleontology (Driscoll, 1965, 1969) palynology (See, 1980), stratigraphy (Harrell and others, 1991; Lilienthal, 1978; Monnett, 1948; Pawlowicz, 1969; Shaver, 1985), and sedimentology (Harrell and others, 1991; O’Hara, 1954; Potter and Pryor, 1961; Rorick, 1983).

\section{Michigan Formation}

The Michigan Formation is an interbedded sequence of shale, limestone, dolomite, gypsum or anhydrite, and discontinuous beds of siltstone and sandstone (listed in order of decreasing abundance). The cumulative thickness of all lithologies is typically 300 to $400 \mathrm{ft}$ (Harrell and others, 1991). Geophysical logs were used by RASA investigators to delineate boundaries of the Michigan Formation. Examination of these logs shows that thickness of individual strata typically is less than $10 \mathrm{ft}$, and the thin-bedded character and marked contrast in lithology results in erratic changes in geophysical-log traces (Appendix B). Generally, 6 to 10 gypsum beds are intercalated with shale and (or) limestone and (or) dolomite. In most areas of the basin, a sequence of three gypsum beds (commonly referred to as "triple gyp," Lilienthal, 1978, p. 5) shows as a distinctive signature on electrical-resistivity logs. These distinctive gypsum beds are separated from the top of the Marshall Sandstone by various thicknesses of Michigan Formation strata, depending on location in the basin (110 to $140 \mathrm{ft}$ in west, $220 \mathrm{ft}$ in the east, more than $300 \mathrm{ft}$ in the north, unknown in the south). Gypsum beds generally are thickest (some beds 20 to $30 \mathrm{ft}$ in thickness) in the eastern and northeastern parts of the basin, and these relatively thick beds underlie the "triple gyp" strata.

In many areas of the Michigan Basin, sandstones at the base of the Michigan Formation were exploited for natural gas. There has been substantial debate regarding the origin and stratigraphic affinity of natural-gas-bearing sandstones deposited during the interval between Early and Late Mississippian time. Some geologists argue that natural-gas-bearing sandstones that are areally extensive interfinger with the Napoleon Sandstone and are part of the late Marshall sedimentary sequence (Ells, 1979; Harrell and others, 1991; Thomas, 1931). Analysis of geophysical data by RASA investigators supports that interpretation. One factor that complicates interpretation of stratigraphy, is that sandstones of Mississippian age were deposited in two very different sedimentary environments. One depositional environment produced areally extensive blanket sandstones ${ }^{1}$, in which natural gas was contained along the closures of north- to northwest-trending anticlines. The other depositional environment produced elongate, laterally discontinuous sandstone bodies that contained natural gas. These discontinuous sandstones may have formed as offshore sandbars, as suggested by Ball and others (1941). Typically, these elongate discontinuous sandstone bodies are thin (usually less than $10 \mathrm{ft}$, but as thick as $30 \mathrm{ft}$ ) and intercalated with evaporite, dolomite, limestone, and shale.

\footnotetext{
${ }^{1}$ Blanket sand, as defined by Bates and Jackson (1987, p. 74), is a "deposit of sand or sandstone of unusually wide distribution, typically an orthoquartzitic sandstone deposited by a transgressive sea advancing for a considerable distance over a stable shelf area."
} 
The common practice during the early 1930's through the 1950's, a period of considerable exploration for natural gas in Mississippian sandstones, was to name any gas-bearing sandstone the "Michigan stray sandstone" (Newcombe, 1933, p. 196). The problem with this informal stratigraphic name is that natural gas was discovered in multiple, stacked horizons of discontinuous sandstones, as well as in blanket sandstones. Hard (1938) constructed fence diagrams that show relations of discontinuous sandstone bodies to blanket sandstones (Napoleon and lower Marshall sandstone). His diagrams illustrate as many as three separate "stray sandstone" horizons above the Napoleon Sandstone. For purposes of characterization of hydrogeologic framework of the regional aquifer system, RASA investigators consider blanket sandstones to be part of the Marshall sedimentary sequence; elongate discontinuous sandstone bodies are considered to be part of the Michigan Formation.

Previous investigations of the Michigan Formation focused on economic geology (Briggs, 1970; Cohee and others, 1951; Hake, 1938; Hard, 1938; Harrell and others, 1991; Newcombe, 1933), general geology (Dorr and Eschman, 1970; Ells, 1979), hydrogeology (Mandle and Westjohn, 1989; Westjohn and Weaver, 1994), and sedimentology and stratigraphy (Cohee, 1965, 1979; Harrel and others, 1991; Lilienthal, 1978; McGregor, 1954; Moser, 1963; Olszewski, 1978; Shaver, 1985). Extensive bibliographies of previous investigations of the Michigan Formation are included in publications by Harrell and others (1991), Martin and Straight (1956), and Moser (1963).

\section{HYDROGEOLOGIC FRAMEWORK OF MISSISSIPPIAN ROCKS}

The stratigraphic units previously discussed are divided into three hydrogeologic units (fig. 3): the Michigan confining unit, the Marshall aquifer, and the Coldwater confining unit. Explanations of the relations of stratigraphic units to hydrogeologic units, and methods used to delineate boundaries of hydrogeologic units are followed by discussion of the areal extent, thickness, surface configuration, hydraulic properties, and use and quality of water of each of these units.

\section{Relations of Stratigraphic Units to Aquifer and Confining Units}

Relations of stratigraphic names to hydrogeologic nomenclature established for the Michigan Basin RASA study are shown in figure 3. Also shown are lithologic constituents of formations and thicknesses of the Marshall aquifer and Michigan and Coldwater confining units. Boundaries of these units were delineated on the basis of hydraulic properties. Thus, a hydrogeologic unit may consist of part or all of a formation. For example, sandstone is present at or near the base of the Mississippian Michigan Formation in many areas of the basin. Some previous investigators suggest that these sandstones should be assigned to the Michigan Formation (for example, Hake, 1938; Hard, 1938; Michigan Geological Survey, 1964). Others interpret stratigraphically continuous sandstones to be part of the Marshall sedimentary sequence (Ells, 1979; Harrell and others, 1991). It is generally not possible to distinguish these sandstones at the base of the Michigan Formation from underlying Mississippian sandstones (Napoleon or Marshall Sandstone; Monnett, 1948). Regardless of stratigraphic relations, relatively thick, blanket-type, stratigraphically continuous Mississippian sandstones between the Coldwater Shale and Michigan Formation are assumed to be hydraulically connected at the scale of the RASA study area, and collectively they form the Marshall aquifer (fig. 3). In contrast, the Mississippian Coldwater Shale (formal stratigraphic nomenclature) and Coldwater confining unit (hydrogeologic name) refer to the same geologic unit (fig. 3). The Coldwater Shale consists mostly of shale, and this formation forms a confining unit throughout the study area. Stratigraphic names 
and hydrogeologic unit nomenclature are used in this report, depending on whether the topic of discussion is geology or hydrogeology.

\section{Delineation of Aquifer- and Confining-Unit Boundaries}

Of the numerous detailed studies of geologic units in the Michigan Basin, most have focused on stratigraphy, sedimentology, and depositional environment (Allen and others, 1916; Cohee and others, 1951; Lane, 1902, 1905; Martin, 1936; Martin and Straight, 1956; Milstein, 1987; Newcombe, 1933; O'Hara, 1954; Moser, 1963; Potter and Pryor, 1961; Rorick, 1983; Winchell, 1869). Maps generated as part of these studies delineate boundaries or thicknesses of formations. A literature search done as part of the RASA investigation failed to locate maps that depict boundaries of hydrogeologic units. Thickness and surface-configuration maps included with this report delineate aquifer- and confining-unit boundaries rather than contacts of different stratigraphic units.

Geophysical logs of oil and gas wells were used to establish hydrogeologic characteristics and map hydrostratigraphic units in the central part of the basin. In areas where geophysical logs are sparse or nonexistent, information from geologic logs of oil, gas, and water wells was used to delineate aquifer- and confining-unit boundaries. In Appendix B, example geophysical logs are provided, and methods used to delineate aquifer- and confining-unit boundaries by interpretation of geophysical and geologic logs are described.

\section{Description of Confining Units and the Marshall Aquifer}

\section{Michigan Confining Unit}

The Michigan confining unit is the composite of all confining-unit lithologies of the Michigan Formation. This confining unit separates the Parma-Bayport aquifer from the underlying Marshall aquifer (fig. 3). The Michigan confining unit consists of shale, carbonate, evaporite, and thin, laterally discontinuous siltstone and sandstone lenses. The sandstone/siltstone lenses are intercalated with evaporite, shale, dolomite, and limestone. These intercalated units probably do not contribute a significant quantity of ground water to the regional flow system.

\section{Areal Extent, Surface Configuration, and Thickness}

The Michigan confining unit is present in most of the RASA study area, and its areal extent is approximately $17,000 \mathrm{mi}^{2}$. Surface configuration of this confining unit is shown in figure 4. Altitudes of the top of the Michigan confining unit are lowest in the north-central part of the study area, where altitudes are more than $200 \mathrm{ft}$ below sea level. The surface of the confining unit is highest in the south and east, where altitudes are approximately $900 \mathrm{ft}$ and $600 \mathrm{ft}$ above sea level, respectively. In the west and north, altitudes of the top of the confining unit generally range from 300 to $400 \mathrm{ft}$ above sea level.

The Michigan confining unit generally thickens from south to north (fig. 5). In the northwestern part of the study area, the confining unit typically ranges from 300 to $400 \mathrm{ft}$ in thickness. The unit thins to $100 \mathrm{ft}$ in the south and east. In the northeastern part of the mapped area, the unit is less than $50 \mathrm{ft}$ thick in places. The locations of boreholes and logs used to construct surfaceconfiguration and thickness maps of the Michigan confining unit are shown in Appendix $\mathrm{C}$. 


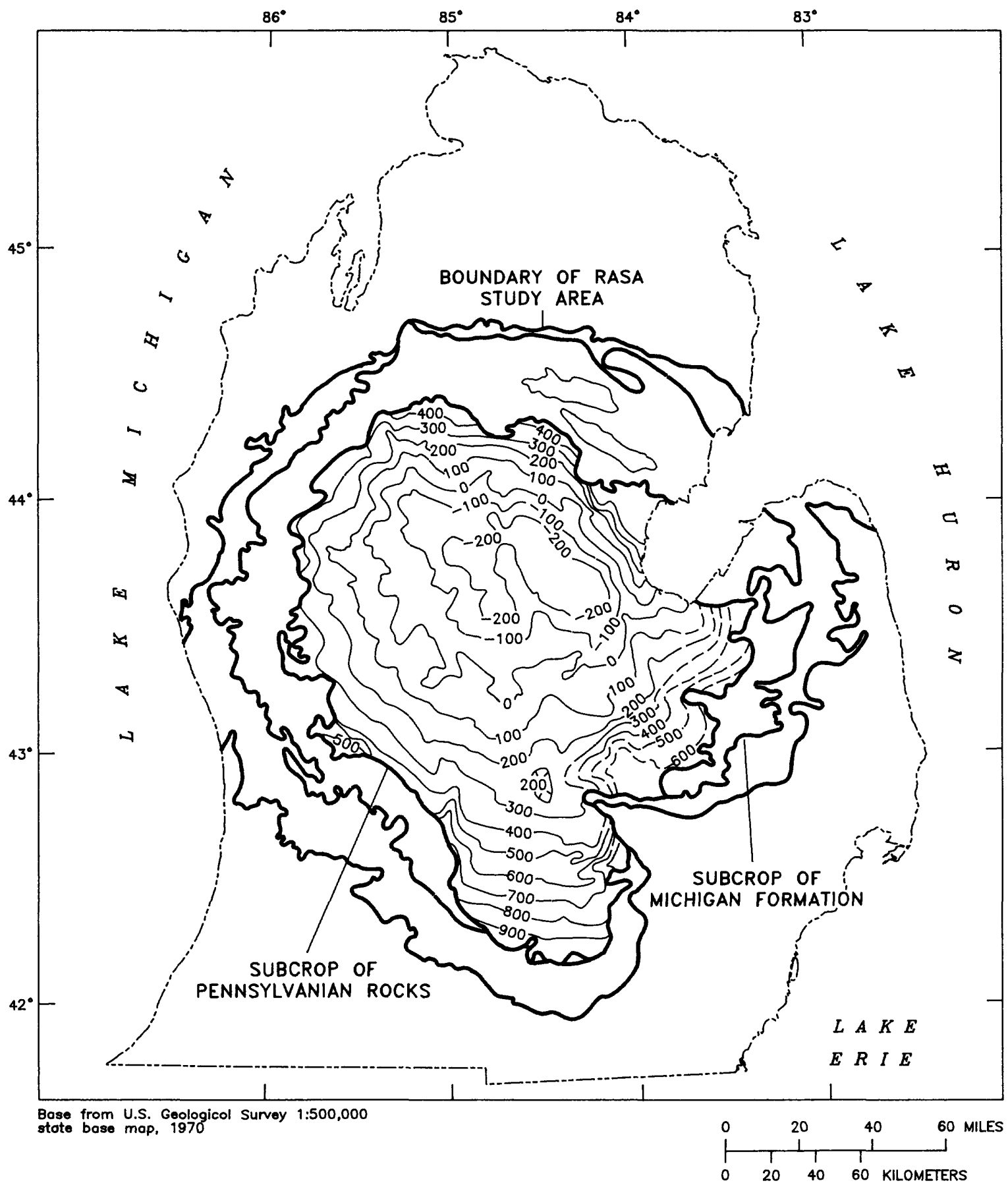

EXPLANATION

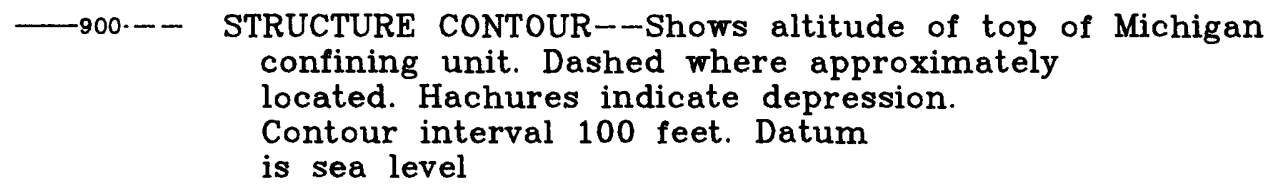

Figure 4. Surface configuration of Michigan confining unit in the central Lower Peninsula of Michigan. 


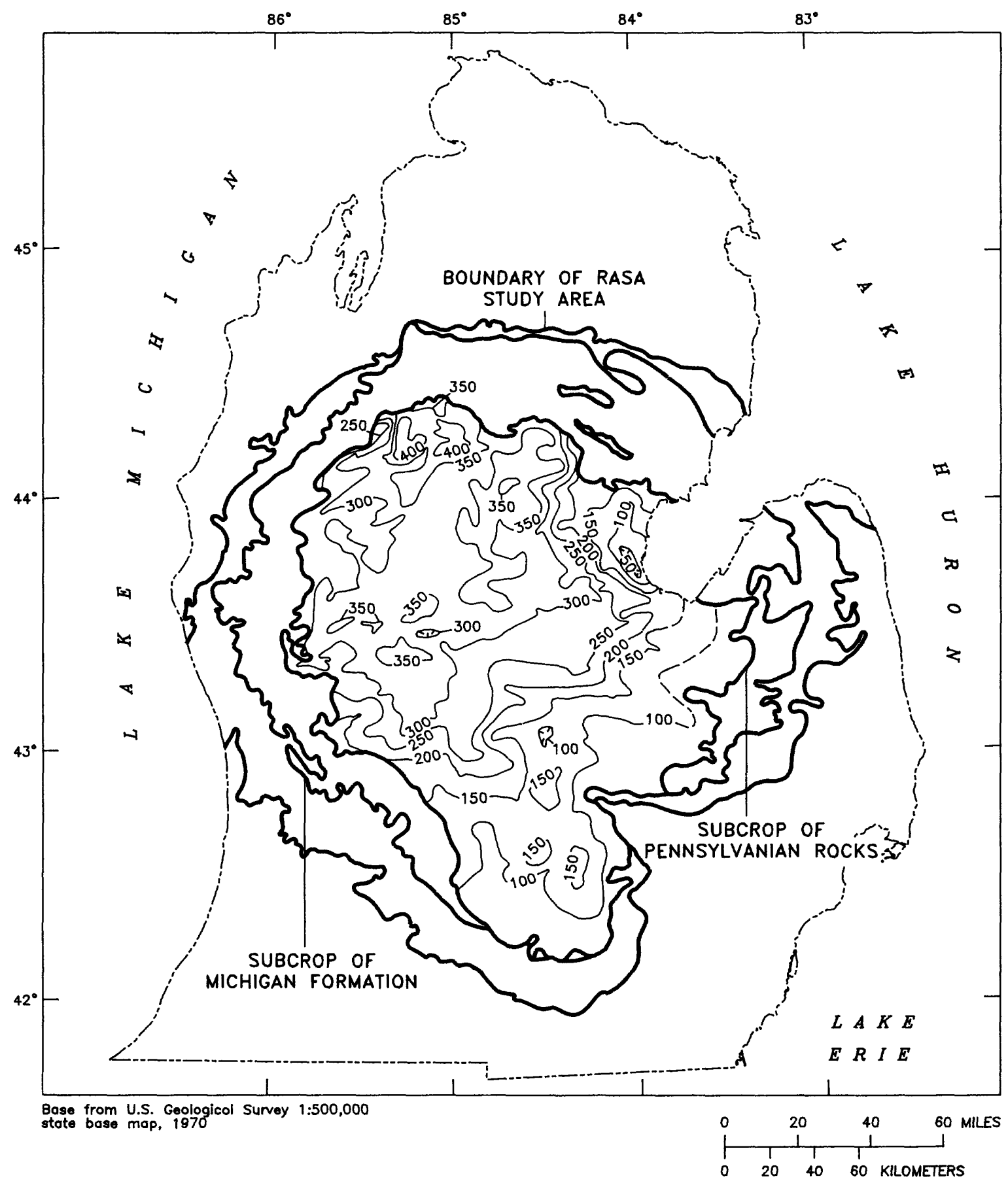

EXPLANATION

-100--- LINE OF EQUAL THICKNESS--Shows thickness of Michigan confining unit. Dashed where approximately located. Hachures indicate depression. Contour interval 50 feet. Datum is sea level

Figure 5. Thickness of Michigan confining unit in the central Lower Peninsula of Michigan. 


\section{Hydraulic Properties}

No hydraulic-property data are available for the Michigan confining unit. Evidence that the unit functions as a confining unit are the wide-spread reservoirs of natural gas trapped in sandstones below gypsum, anhydrite, limestone, or dolomite beds of the Michigan confining unit (Rawlins and Schellhardt, 1936).

\section{Use and Quality of Water}

Few water wells are completed in the Michigan Formation, because potable water is available from overlying glaciofluvial and Saginaw aquifers. In areas where the Michigan Formation is in direct hydraulic connection with glacial deposits, some water wells for domestic supply are completed in the confining unit. Dissolved-solids concentration of ground water sampled from wells completed in the Michigan confining unit in subcrop areas ranges from 240 to $6,800 \mathrm{mg} / \mathrm{L}$, and predominant solutes are typically calcium sulfate or calcium bicarbonate (Dannemiller and Baltusis, 1990).

\section{Marshall Aquifer}

The Marshall aquifer consists of all blanket-type sandstones of Mississippian age, but it does not include thin, laterally discontinuous sandstone lenses intercalated with typical Michigan Formation lithologies. The Marshall aquifer consists of one or more permeable sandstones that are assumed to be hydraulically connected at the scale of the regional aquifer system. Delineation of permeable sandstones by use of geophysical logs is described in Appendix B, and by Westjohn $(1989,1994)$.

\section{Areal Extent, Surface Configuration, and Thickness}

The Marshall aquifer is laterally continuous throughout the RASA study area, and the areal extent of this aquifer is approximately $22,000 \mathrm{mi}^{2}$. Surface configuration of the Marshall aquifer is shown on figure 6. Altitudes of the top of the aquifer are lowest in the central part of the basin, where the top of the unit is more than $600 \mathrm{ft}$ below sea level. The top of the aquifer is highest toward the boundary of the study area. In the south, altitude of the top of the aquifer is more than $800 \mathrm{ft}$ above sea level. Highest altitudes range from 300 to $400 \mathrm{ft}$ in the west and from 500 to $700 \mathrm{ft}$ above sea level in the north. Altitudes in the east generally range from 500 to $600 \mathrm{ft}$ above sea level. Locations of boreholes and logs used to construct the surface-configuration map of the Marshall aquifer are shown in Appendix C.

Only permeable sandstones are considered to constitute aquifer material, and all other lithologies were excluded in the preparation of the Marshall aquifer thickness map (fig. 7). Thickness of the Marshall aquifer is 75 to $125 \mathrm{ft}$ in most of eastern and southern parts of the RASA study area. The aquifer thins to approximately $75 \mathrm{ft}$ along a northwest-trending corridor from Livingston County to Newaygo County. The aquifer is more than $200 \mathrm{ft}$ thick in the northwestern part of the study area (Wexford County and Osceola County, figs. 1 and 7). The locations of boreholes, gamma-ray logs, and electrical-resistivity logs used to construct the thickness map of the Marshall aquifer are shown in Appendix C. 


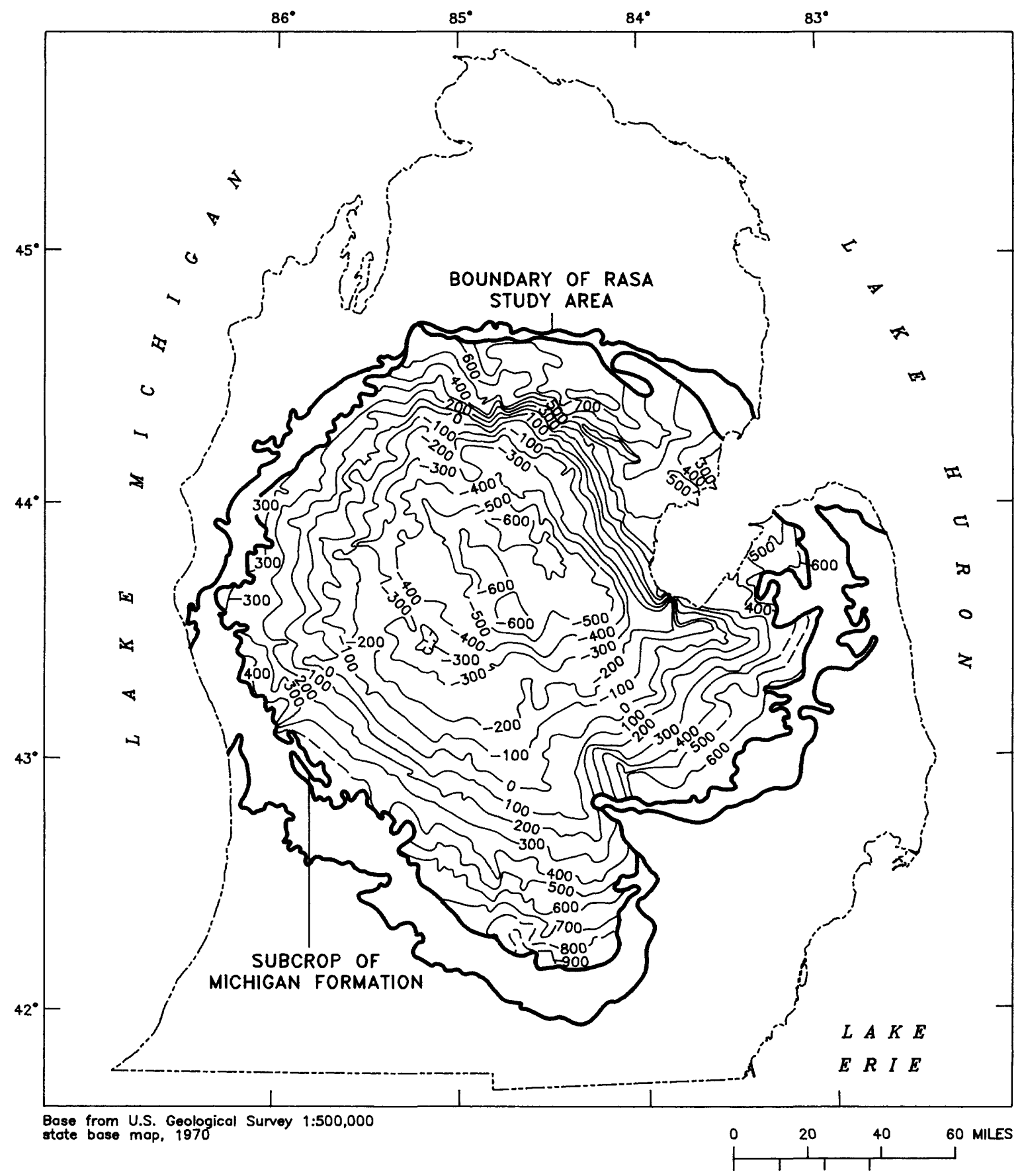

EXPLANATION

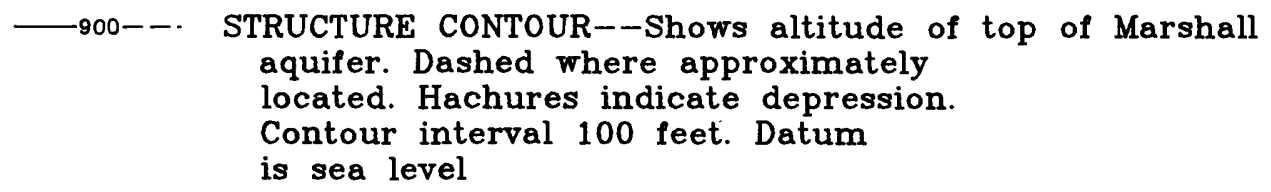

Figure 6. Surface configuration of Marshall aquifer in the central Lower Peninsula of Michigan. 


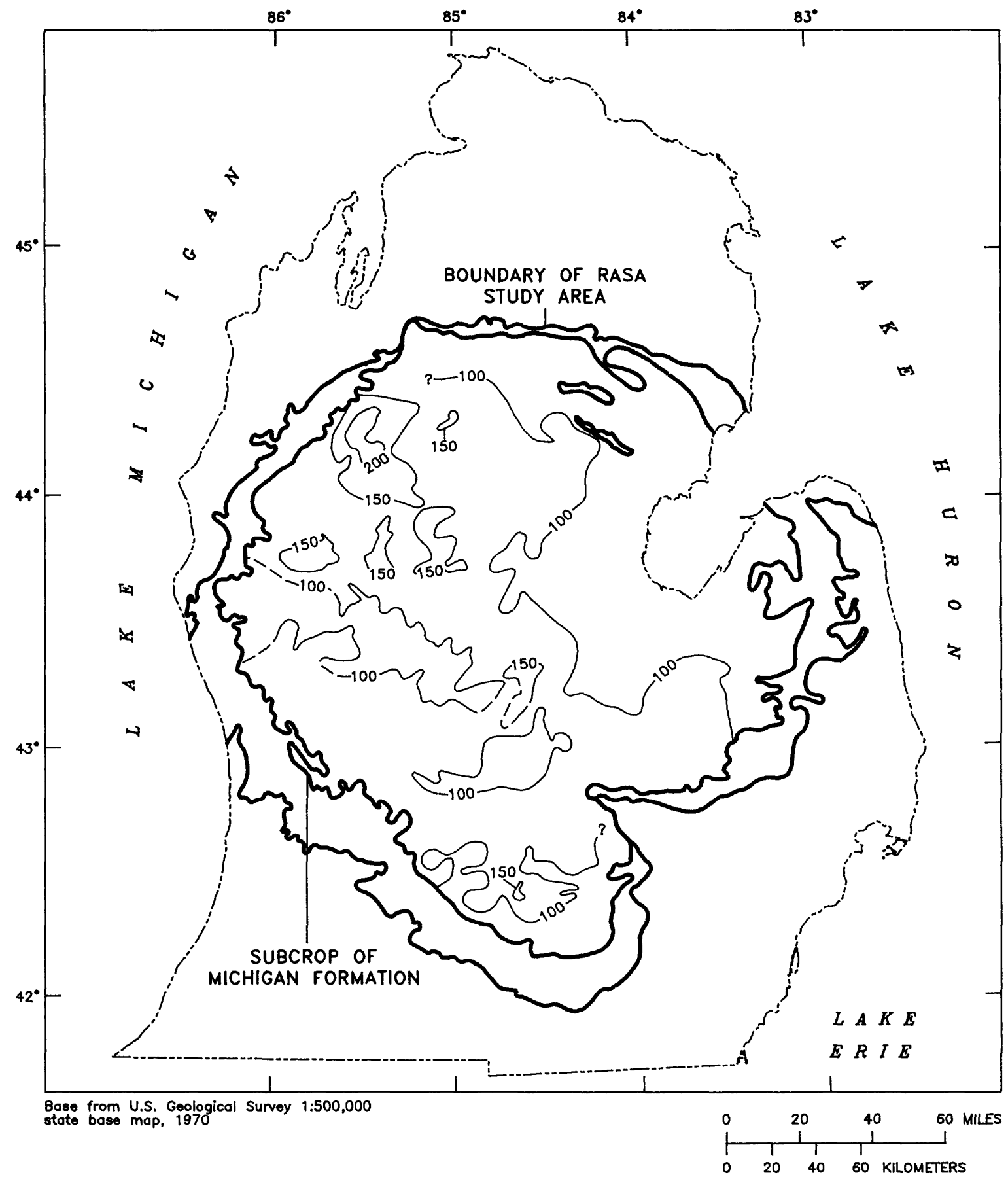

EXPLANATION

-100--- LINE OF EQUAL THICKNESS--Shows thickness of Marshall aquifer. Dashed where approximately located. Hachures indicate depression. Contour interval 50 feet. Datum is sea level

Figure 7. Thickness of Marshall aquifer in the central Lower Peninsula of Michigan. 


\section{Hydraulic Properties}

Hydraulic properties of the Marshall aquifer have been interpreted from aquifer tests at Battle Creek and Jackson, two large municipalities in the southern part of the study area (fig. 1). The aquifer is highly productive in these areas, and each municipality withdraws more than $10 \mathrm{Mgal} / \mathrm{d}$ of ground water (Grannemann and others, 1985). Large ground-water withdrawals are possible at these sites because the Marshall aquifer is highly fractured. Transmissivities determined from aquifer tests at the Verona well field in Battle Creek, Mich. (fig. 1) range from 3,000 to 27,000 $\mathrm{ft}^{2} / \mathrm{d}$ (Grannemann and Twenter, 1985, p. 25). These transmissivities are based on constant hydraulic conductivities of 150 and $550 \mathrm{ft} / \mathrm{d}$. Transmissivities of the Marshall aquifer determined from aquifer tests at the Jackson well field range from 7,500 to $29,000 \mathrm{ft}^{2} / \mathrm{d}$ (George Econ, Jackson Community College, written commun., 1993).

In other areas of the basin, the Marshall aquifer is substantially less productive. Transmissivities determined from aquifer tests in Huron County (fig. 1) range from 7 to $50 \mathrm{ft}^{2} / \mathrm{d}$, and hydraulic conductivities range from 0.2 to $1.5 \mathrm{ft} / \mathrm{d}$ (Sweat, 1992). Similar ranges of hydraulic properties were derived from double-packer aquifer tests done as part of the Michigan Basin RASA study (Westjohn, 1993). Analysis of aquifer tests of the Marshall aquifer in three counties (Muskegon, Genesee, and Eaton Counties; fig. 1) indicate a small range of transmissivities (10 to $37 \mathrm{ft}^{2} / \mathrm{d}$ ) and hydraulic conductivities $(0.2$ to $0.5 \mathrm{ft} / \mathrm{d})$.

Hydraulic properties of sandstone cores sampled from the Marshall aquifer were measured as part of the Michigan Basin RASA investigation. Porosity was measured of 63 sandstone cores, vertical hydraulic conductivity was measured of 43 samples, and horizontal hydraulic conductivity was measured of 20 samples. The porosity and hydraulic-conductivity data are summarized in Appendix D.

The suite of sandstone specimens selected for laboratory measurements of hydraulic properties are well cemented, unfractured sandstones, so the measurements reflect matrix-controlled hydraulic properties. The upper range of matrix-controlled hydraulic conductivities measured of cores (1.3 to $1.8 \mathrm{ft} / \mathrm{d}$ ) is similar to higher hydraulic conductivities determined from aquifer tests in several counties. These similarities indicate that fractures are absent in the Marshall aquifer at these localities and that ground-water flow in the aquifer is dominated by matrix-hydraulic properties of sandstones.

\section{Use and Quality of Water}

The Marshall aquifer is a source of water supply in more than $\mathbf{4 0}$ municipalities in the southern and eastern parts of the study area (Baltusis and others, 1992). Water quality in the Marshall aquifer is suitable for most uses in subcrop areas, where this unit is in direct hydraulic connection with glacial deposits (Westjohn, 1994a; Westjohn and Weaver, 1996b). Wells completed in the Marshall aquifer in parts of at least 21 counties in the study area produce water with dissolved solids concentrations less than $1,000 \mathrm{mg} / \mathrm{L}$ (Dannemiller and Baltusis, 1990). Depths of wells that produce freshwater from the Marshall aquifer are less than $400 \mathrm{ft}$, except in five counties (Arenac, Genesee, Lapeer, Livingston, and Tuscola, see fig. 1), where wells 400 to $432 \mathrm{ft}$ deep yield freshwater.

Down regional dip from subcrop areas, where the Marshall aquifer is overlain and confined (partially or completely) by the Michigan confining unit, salinity of ground water increases. The width of the transition zone where saline water is present in the aquifer ranges from 10 to $30 \mathrm{mi}$ in most of the study area but is as narrow as 2 to $4 \mathrm{mi}$ in the northwest (Westjohn, 1989; Westjohn and Weaver, 1996b). The areal extent of the brine-bearing part of the Marshall aquifer is approximately 
$10,000 \mathrm{mi}^{2}$ (Westjohn, 1989; Westjohn and Weaver, 1996b). Dissolved-solids concentration as large as $337,000 \mathrm{mg} / \mathrm{L}$ is found in the central part of the basin (Western Michigan University, 1981, pl. 24).

\section{Coldwater Confining Unit}

The Coldwater confining unit forms the base of the regional aquifer system. This confining unit consists mostly of shale; siltstone, sandstone, limestone, and dolomite constitute part of this hydrogeologic unit in some areas of the basin. The Coldwater confining unit is approximately $1,300 \mathrm{ft}$ thick in the eastern part of the study area (John Esch, Michigan Department of Natural Resources, written commun., 1994), but it thins to approximately $500 \mathrm{ft}$ in the western part (Cohee, 1979). Although the cumulative thickness of sandstone and siltstone lenses ranges from 100 to $200 \mathrm{ft}$ in parts of the Thumb Area (fig. 2; Cohee, 1979), these lenses of sandstone and siltstone are laterally discontinuous and are separated from the overlying Marshall aquifer by shale. These sandstone and siltstone lenses probably do not contribute a significant amount of ground water to the regional-flow system.

\section{Areal Extent and Surface Configuration}

The areal extent of the Coldwater confining unit is more than $32,000 \mathrm{mi}^{2}$. This unit extends south into northern Indiana and Ohio. The subcrop of this confining unit also extends west under Lake Michigan and east under Lake Huron. The surface configuration of the Coldwater confining unit (fig. 8) is similar to surface configurations of the Michigan confining unit (fig. 4) and Marshall aquifer (fig. 6). Altitudes of the top of the Coldwater confining unit are more than $800 \mathrm{ft}$ below sea level in the central part of the Michigan Basin. Altitudes are highest in the northern and southern parts of the aquifer system (700 to $800 \mathrm{ft})$, lowest in the west $(300 \mathrm{ft})$, and intermediate in the east $(600 \mathrm{ft})$. The locations of boreholes and logs used to construct the surface-configuration map of the Coldwater confining unit are shown in Appendix C.

\section{Hydraulic Properties}

No data on hydraulic properties are known to have been published for the Coldwater confining unit. Laboratory measurements of porosity and hydraulic conductivity have been made of cores of the basal part of the Marshall sedimentary sequence (Appendix D). Vertical and horizontal hydraulic conductivities of these rocks are generally two to three orders of magnitude less than those of overlying permeable sandstones (either lower Marshall sandstone or Napoleon Sandstone). Shales that form the bulk of the Coldwater confining unit are assumed to have lower hydraulic conductivities than the micaceous sandstones/siltstones at the base of the Marshall aquifer; hence, the Coldwater confining unit probably does not contribute a significant amount of ground water to the regional-flow system.

\section{Use and Quality of Water}

Water wells are rarely completed in the Coldwater confining unit because potable water is generally available in overlying glacial deposits or bedrock aquifers. Water wells are occasionally completed in the Coldwater confining unit in areas where it subcrops beneath glacial drift (southern subcrop area, fig. 2). In many counties in the southern part of the State where the Coldwater 


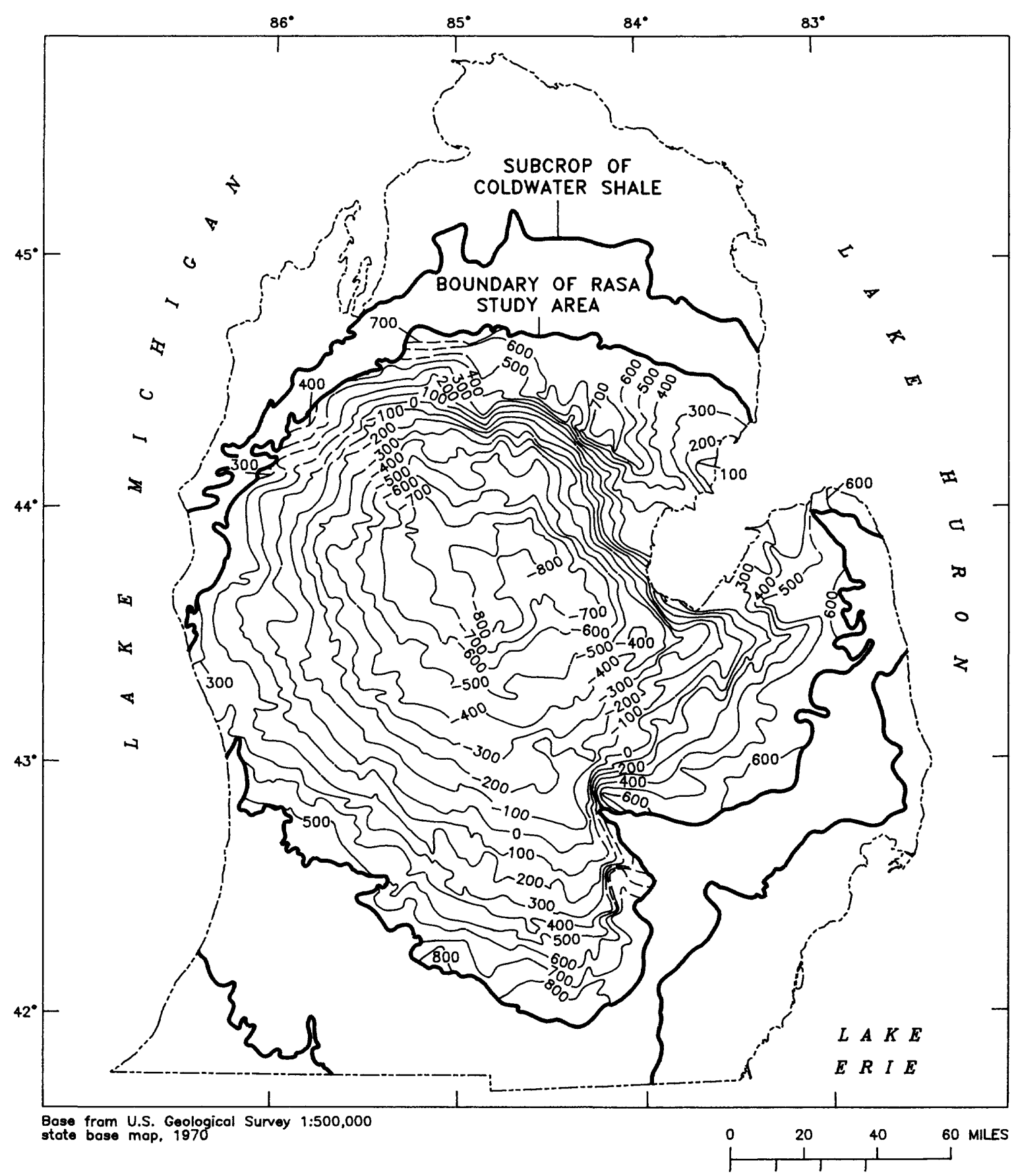

EXPLANATION

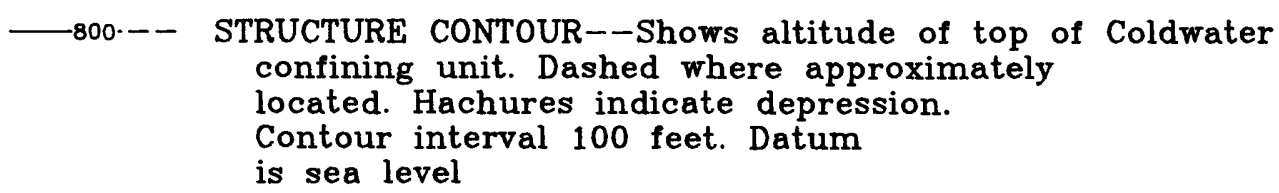

Figure 8. Surface configuration of Coldwater confining unit in the central Lower Peninsula of Michigan. 
confining unit subcrops, glacial deposits are predominantly clay-rich tills, and glaciofluvial deposits or other aquifer material of glacial origin are absent. In these areas, the Coldwater confining unit is commonly explored for potential development of water supply. In some places, the Coldwater confining unit will produce small quantities of water of acceptable quality for domestic supply; typically, however, ground water contains a high concentration of dissolved solids (greater than 1,000 mg/L) (Mark Breithart, Michigan Department of Public Health, oral commun., 1994). In the Thumb Area of Michigan (fig. 1), ground water sampled from six wells completed in the Coldwater confining unit had concentrations of dissolved solids that ranged from 17,700 to $39,000 \mathrm{mg} / \mathrm{L}$ (Sweat, 1992, p. 73).

\section{SUMMARY}

Sedimentary rocks of Mississippian age form the lower part of a regional system of aquifers and confining units in the central part of the Lower Peninsula of Michigan. Strata of the Michigan Formation, the Marshall Sandstone, and Coldwater Shale were subdivided into an aquifer and two confining units on the basis of hydraulic properties. Surface-configuration and thickness maps of these aquifer-system units were prepared by USGS hydrogeologists, to aid in characterization of the hydrogeologic framework of the Michigan Basin RASA study area. These maps delineate boundaries of aquifer-system units for purposes of numerical simulation ground-water flow.

The Michigan confining unit consists of shale, limestone, dolomite, gypsum/anhydrite, and isolated lenses of siltstone and sandstone. This confining unit is laterally continuous, typically ranges from 300 to $400 \mathrm{ft}$ in thickness, and has an areal extent of about $17,000 \mathrm{mi}^{2}$.

The Michigan confining unit overlies the Marshall aquifer, which consists of one or more stratigraphically continuous permeable sandstones. In areas where the Marshall aquifer consists of two or more sandstones, these permeable strata typically are separated by beds of siltstone, shale and (or) carbonate. It is assumed that areally extensive Mississippian sandstones that form the Marshall aquifer are hydraulically connected at the scale of the regional aquifer system, and this aquifer unit forms a single layer for purposes of numerical simulation of ground-water flow. The composite of permeable sandstones that form the Marshall aquifer typically ranges from 75 to $125 \mathrm{ft}$ in thickness, and the areal extent of this regional aquifer is about $22,000 \mathrm{mi}^{2}$. The Marshall aquifer is freshwater bearing in areas where it subcrops and is in direct hydraulic connection to Pleistocene glacial deposits. Down regional dip and away from subcrop areas, where the Marshall aquifer is partially or entirely confined by the Michigan confining unit, salinity of ground water in this aquifer progressively increases. The transition zone from freshwater to brine in the Marshall aquifer is about 20 mi in width in the southern part of the aquifer system, and approximately $10 \mathrm{mi}$ in width in the northern part. The Marshall aquifer contains brine in the central part of the basin (areal extent about $10,000 \mathrm{mi}^{2}$ ), where this unit is more than $800 \mathrm{ft}$ below land surface.

The Coldwater confining unit underlies the Marshall aquifer and forms the basal part of the regional aquifer system. This confining unit is about $1,100 \mathrm{ft}$ in thickness in most of the eastern part of the aquifer system, but it thins to about $500 \mathrm{ft}$ in the western part of the mapped area. The Coldwater confining unit consists mostly of shale, but carbonate beds constitute part of the confining unit in west-central part of the basin. There are sandstone/siltstone lenses interbedded with shale of the Coldwater confining unit in the east-central part of the basin. The composite thickness of these more permeable strata ranges from 100 to $200 \mathrm{ft}$ in the Thumb area of the State, but these beds are separated from the overlying Marshall aquifer by shale. Interpretations of geophyiscal logs indicate that siltstone and sandstone beds are thin and laterally discontinuous; they probably do not contribute a substantial amount of ground water to the regional-flow system. 


\section{REFERENCES CITED}

Allen, R.C., Smith, R.A., and Barrett, L.P., 1916, Geological map of Michigan: Michigan Geological and Biological Survey, Publication 23, Geological Series 19, scale 1:750,000.

Asquith, George, and Gibson, Charles, 1982, Basic well log analysis for geologists: Tulsa, Okla., American Association of Petroleum Geologists, 215 p.

Ball, M.W., Weaver, T.J., Crider, H.D., and Ball, D.S., 1941, Shoestring gas fields of Michigan, in Levorsen, A.I., ed., Stratigraphic type oil fields: American Association of Petroleum Geologists, p. 237-266.

Baltusis, M.A., Quigley, M.F., and Mandle, R.J., 1992, Municipal ground-water development and withdrawals in the central Lower Peninsula of Michigan, 1870-1987: U.S. Geological Survey Open-File Report 91-215, 89 p.

Bates, R.L., and Jackson, J.A., eds., 1987, Glossary of geology (3d ed.): Alexandria, Va., American Geological Institute, $788 \mathrm{p}$.

Briggs, L.I., 1970, Geology of gypsum in the Lower Peninsula, Michigan, in 6th Proceedings, Forum on geology of industrial minerals: Michigan Geological Survey Miscellaneous Publication 1, p. 66-76.

Chung, P.K., 1973, Mississippian Coldwater Formation of the Michigan Basin: East Lansing, Mich., Michigan State University, Ph.D. dissertation, 159 p.

Cohee, G.V., 1965, Geologic history of the Michigan Basin: Washington Academy of Science Journal, v. 55, p. 211-233. 1979, Michigan Basin region, in Craig, L.C., and Connor, C.W., eds., Paleotectonic investigations of the Mississippian System in the United States, Part I-Introduction and regional analyses of the Mississippian System: U.S. Geological Survey Professional Paper 1010, p. 49-57.

Cohee, G.V., Macha, Carol, and Holk, Margery, 1951, Thickness and lithology of Upper Devonian and Carboniferous rocks: U.S. Geological Survey Oil and Gas Investigations Preliminary Chart OC-41.

Dannemiller, G.T., and Baltusis, M.A., Jr., 1990, Physical and chemical data for ground water in the Michigan Basin, 1986-89: U.S. Geological Survey Open-File Report 90-368, 155 p.

Dorr, J.A., Jr., and Eschman, D.F., 1970, Geology of Michigan: Ann Arbor, Mich., University of Michigan Press, $476 \mathrm{p}$.

Driscoll, E.G., 1965, Dimyarian pelecypods of the Mississippian Marshall Sandstone of Michigan: Palaeotographica Americana, v. 5, no. 35, p. 67-128. 1969, Animal-sediment relationships of the Coldwater and Marshall Formations of Michigan, in Campbell, K.S.W., ed., Stratigraphy and paleontology essays in honor of Dorothy Hill: Canberra, Australia National University Press, p. 337-352.

Ells, G.D., 1979, Michigan, chap. $J$ of The Mississippian and Pennsylvanian (Carboniferous) Systems in the United States: U.S. Geological Survey Professional Paper 1110, p. J1-J17.

Grannemann, N.G., and Twenter, F.R., 1985, Geohydrology and ground-water flow at Verona well field, Battle Creek, Michigan: U.S. Geological Survey Water-Resources Investigations Report $85-4056,54 \mathrm{p}$.

Grannemann, N.G., Twenter, F.R., Huffman, G.C., and Cummings, T.R., 1985, Michigan ground-water resources, in U.S. Geological Survey, National Water Summary, 1984Hydrologic events, selected water quality trends, and ground-water resources: U.S. Geological Survey Water-Supply Paper 2275, p. 255-260.

Hake, B.F., 1938, Geologic occurrence of oil and gas in Michigan: American Association of Petroleum Geologists Bulletin, v. 22, p. 393-415. 
Hale, Lucille, 1941, Study of sedimentation and stratigraphy of Lower Mississippian in western Michigan: American Association of Petroleum Geologists Bulletin, v. 25, p. 713-723.

Hard, E.W., 1938, Mississippian gas sands of central Michigan area: American Association of Petroleum Geologists Bulletin, v. 22, no. 2, p. 129-174.

Harrell, J.A., Hatfield, C.B., and Gunn, G.R., 1991, Mississippian System of the Michigan Basin; stratigraphy, sedimentology, and economic geology, in Catacosinos, P.A., and Daniels, P.A., Jr., eds., Early sedimentary evolution of the Michigan Basin: Geological Society of America Special Paper 256, p. 203-219.

Hearst, J.R., and Nelson, P.H., 1985, Well logging for physical properties: New York, McGraw-Hill, 571 p.

Hilchie, D.W., 1979, Old electric log interpretation: Golden, Colo., D.W. Hilchie, 161 p.

Kropschot, R.E., 1953, A qualitative sedimentary analysis of the Mississippian deposits in the Michigan Basin: East Lansing, Mich., Michigan State University, M.S. thesis, 57 p.

Lane, A.C., 1902, Third annual report of the State Geologist for the year 1901: Michigan Geological Survey Annual Report 1901, 304 p.

1905, Fifth annual report of the State Geologist for the year 1903: Michigan Geological Survey Annual Report 1903, 342 p.

Lilienthal, R.T., 1978, Stratigraphic cross-sections of the Michigan Basin: Michigan Geological Survey Report of Investigations 19, 33 p., 89 pls.

McGregor, D.J., 1954, Stratigraphic analysis of upper Devonian and Mississippian rocks in the Michigan Basin: American Association of Petroleum Geologists Bulletin, v. 38, p. 2324-2356.

Mandle, R.J., 1986, Plan of study for the Regional Aquifer-Systems Analysis of the Michigan Basin: U.S. Geological Survey Open-File Report 86-494, 23 p.

Mandle, R.J., and Westjohn, D.B., 1989, Geohydrologic framework and ground-water flow in the Michigan Basin, in Swain, L.A., and Johnson, A.I., eds., Regional aquifer systems of the United States, aquifers of the Midwestern area: American Water Resources Monograph series no. 13, p. 83-109.

Martin, H.M., comp., 1936, The Centennial geological map of the southern Peninsula of Michigan: Michigan Geological Survey, Publication 39, Geological Series 33, scale 1:500,000.

Martin, H.M., and Straight, M.T., 1956, An index of the geology of Michigan 1823-1955: Michigan Department of Conservation, Publication 50, 461 p., 13 pls.

Michigan Geological Survey, 1964, Stratigraphic succession in Michigan, Paleozoic through recent: Chart 1.

Milstein, R.L., comp., 1987, Bedrock geology of Southern Michigan: Michigan Geological Survey, scale 1:500,000.

Monnett, V.B., 1948, Mississippian Marshall Formation of Michigan: American Association of Petroleum Geologists Bulletin, v. 32, p. 629-688.

Moser, Frank, 1963, The Michigan Formation-a study in the use of a computer oriented system in stratigraphic analysis: Ann Arbor, Mich., University of Michigan, Ph.D. dissertation, 96 p.

Newcombe, R.B., 1933, Oil and gas fields of Michigan: Michigan Department of Conservation, Geological Survey Division, Publication 38, Geological Series 32, 293 p.

O'Hara, N.W., 1954, A statistical and mechanical analysis of the Marshall Sandstone in western Michigan to determine the environmental pattern of the deposit: East Lansing, Mich., Michigan State College, M.S. thesis, 142 p.

Olszewski, G.P., 1978, An interpretation of the sedimentary environment of the Michigan Formation (Mississippian) in Michigan: Detroit, Mich., Wayne State University, M.S. thesis, 104 p.

Pawlowicz, R.M., 1969, Stratigraphy of the Marshall Formation (Mississippian, Osagian) in southern Michigan: Toledo, Ohio, University of Toledo, M.S. thesis, 43 p. 
Potter, P.E., and Pryor, W.A., 1961, Dispersal centers of Paleozoic and later clastics of the upper Mississippi Valley and adjacent areas: Geological Society of America Bulletin, v. 72, p. 1195-1250.

Rawlins, E.L., and Schellhardt, M.A., 1936, Extent and availability of natural gas reserves in Michigan "Stray" sandstone horizon of central Michigan: U.S. Bureau of Mines Report of Investigations no. $3133,139 \mathrm{p}$.

Rorick, A.H., 1983, Sediment dispersal patterns and provenance of the Marshall Formation (Mississippian) in the Michigan Basin-a petrographic analysis: Toledo, Ohio, University of Toledo, M.S. thesis, 130 p.

See, B.E., 1980, Palynology of the Mississippian Marshall Sandstone and Coldwater Shale of Michigan: Bowling Green, Ohio, Bowling Green State University, M.S. thesis, 66 p.

Shaver, R.H., ed., 1985, Midwestern Basin and Arches Region: COSUNA Correlation Charts, American Association of Petroleum Geologists.

Stearns, M.D., 1933, Petrology of the Marshall Formation of Michigan: Journal of Sedimentary Petrology, v. 3, p. 99-112.

Stearns, M.D., and Cook, C.W., 1931, A petrographic study of the Marshall Formation and its relation to the sands of the Michigan Series: Michigan Academy of Sciences, Arts and Letters, Papers, v. 16, p., 429-437.

Sweat, M.J., 1992, Hydrogeology of Huron County, Michigan: U.S. Geological Survey WaterResources Investigations Report 91-4133, 76 p.

Tarbell, Eleanor, 1941, Antrim-Ellsworth-Coldwater Shale Formations in Michigan: American Association of Petroleum Geologists Bulletin, v. 25, p. 724-733.

Thomas, W.A., 1931, A study of the Marshall formation in Michigan: Michigan Academy Science, Arts and Letters, Papers, v. 14., p. 487-98.

Weeks, J.B., and Sun, R.J., 1987, Regional Aquifer-System Analysis Program of the U.S. Geological Survey-bibliography, 1978-86: U.S. Geological Survey Water-Resources Investigations Report 87-4138, $81 \mathrm{p}$.

Western Michigan University, Department of Geology, 1981, Hydrogeologic Atlas of Michigan: U.S. Environmental Protection Agency Underground Injection Control Program Report, 35 plates, scale 1:500,000.

Westjohn, D.B., 1989, Application of geophysics in the delineation of the freshwater/saline water interface in the Michigan Basin, in Swain, L.A., and Johnson, A.I., eds., Aquifers of the Midwestern Area: American Water Resources Association Monograph series no. 13, p. 111-134. 1993, Regional Aquifer-System Analysis double-packer aquifer tests [abs.], in Latkovich, V.J., ed., Proceeding of a pressure transducer-pack workshop: U.S. Geological Survey Open-File Report 93-71, p. 19-20. 1994a, Geologic controls of the distribution of freshwater in a regional aquifer system-central Michigan Basin [abs.]: Geological Society of America Abstracts with Programs, v. 26, no. 5, p. 67.

1994b, Use of borehole-geophysical logs to delineate the position of the freshwater/saline-water interface in the Michigan Basin, in Paillet, F.L., and Williams, J.H., eds., Proceedings of the U.S. Geological Survey workshop on the applications of borehole geophysics to ground-water investigations: U.S. Geological Survey Water-Resources Investigations Report 94-4103, p. 32-39. 
Westjohn, D.B., and Weaver, T.L., 1994, Geologic setting and hydrogeologic framework of Carboniferous rocks, in Westjohn, D.B., ed., Geohydrology of Carboniferous aquifers in the Michigan Basin, Great Lakes Section-SEPM 1994 fall field guide: Michigan Basin Geological Society, p. B1-B32. 1996a, Hydrogeologic framework of Pennsylvanian and Late Mississippian rocks in the central Lower Peninsula of Michigan: U.S. Geological Survey Water-Resources Investigations Report 94-4107, $44 \mathrm{p}$.

1996b, Configuration of the freshwater/saline-water interface and geologic controls of distribution of freshwater in a regional aquifer system, central Lower Peninsula of Michigan: U.S. Geological Survey Water-Resources Investigations Report 94-4242, 44 p.

Westjohn, D.B., Weaver, T.L., and Zacharias, K.F., 1994, Hydrogeology of Pleistocene glacial deposits and Jurassic "red beds" in the central Lower Peninsula of Michigan: U.S. Geological Survey Water-Resources Investigations Report 93-4152, 14 p.

Winchell, Alexander, 1869, Map of the State of Michigan colored to show the geologic formations, in Atlas of the State of Michigan. [Tackabury Atlas.]

Wooten, M.J., 1951, The Coldwater Formation in the area of the type locality: Detroit, Mich., Wayne State University, M.S. thesis, 52 p.

Zacharias, K.F., Sibley, D.F., and Long, D.T., 1994, Pore water evolution in an intracratonic basin setting, in Westjohn, D.B., ed., Geohydrology of Carboniferous aquifers of the Michigan Basin, Great Lakes Section-SEPM fall field guide: Michigan Basin Geological Society, p. C1-16. 
APPENDIXES 



\section{APPENDIX A. IDENTIFICATION AND LOCATIONS OF GEOPHYSICAL AND GEOLOGIC LOGS, AND GENERALIZED HYDROGEOLOGIC SECTIONS ILLUSTRATING RELATIONS OF AQUIFER-SYSTEM UNITS}

\section{CONTENTS}

Table A1. Identification of geophysical and geologic logs used in the construction of hydrogeologic section A-A', Muskegon County to Crawford County, Michigan . . . 27

Table A2. Identification of geophysical and geologic logs used in the construction of hydrogeologic section B-B', Wexford County to Shiawassee County, Michigan . . . 28

Figure A1. Map showing location of geophysical and geologic logs used in the construction of hydrogeologic sections A-A' and B-B', central Lower Peninsula of Michigan . . . 29

Figure A2. Generalized hydrogeologic section $\mathbf{A}-\mathbf{A}^{\prime}$ showing stratigraphic relations of Mississippian and younger geologic units, Muskegon County to

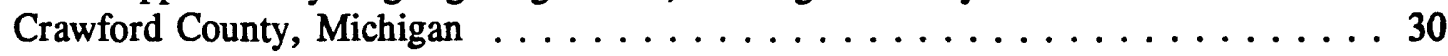

Figure A3. Generalized hydrogeologic section B-B' showing stratigraphic relations of Mississippian and younger geologic units, Wexford County to

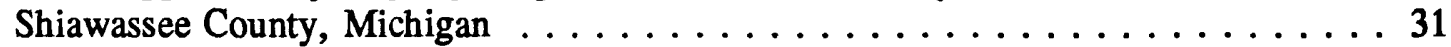



Table A1. Identification of geophysical and geologic logs used in the construction of hydrogeologic section A-A', Muskegon County to Crawford County, Michigan

[Permit numbers are assigned to oil and gas wells by Michigan Department of Natural Resources; dashes indicate that no permit number was issued or that well was used for purposes other than oil or gas exploration or production. U.S. Geological Survey (USGS) identifiers are numbers assigned to logs on file at USGS, indicating county where well is located, type of well, and type of log]

\begin{tabular}{|c|c|c|c|c|}
\hline $\begin{array}{l}\text { Permit } \\
\text { number }\end{array}$ & $\begin{array}{c}\text { Number on } \\
\text { geologic } \\
\text { section }\end{array}$ & $\begin{array}{c}\text { USGS } \\
\text { identifier }\end{array}$ & $\begin{array}{c}\text { Section } \\
\text { Township } \\
\text { Range }\end{array}$ & Township name, county \\
\hline 18227 & 1 & Mk-g12 & $13-11 N-18 W$ & Fruitland, Muskegon \\
\hline$\ldots$ & 2 & Mk-W11 & $16-11 N-17 W$ & Fruitland, Muskegon \\
\hline 1499 & 3 & Mk-g9 & $03-11 N-16 W$ & Dalton, Muskegon \\
\hline- & 4 & $\mathbf{R 2}$ & $30-12 N-15 W$ & Holton, Muskegon \\
\hline 217 & 5 & Mk-g16 & $13-12 \mathrm{~N}-15 \mathrm{~W}$ & Holton, Muskegon \\
\hline 16718 & 6 & $N w-7$ & $01-12 N-14 W$ & Bridgeton, Newaygo \\
\hline 13520 & 7 & Nw-5 & $10-12 N-13 W$ & Garfield, Newaygo \\
\hline 13719 & 8 & $N w-21$ & $11-12 N-13 W$ & Garfield, Newaygo \\
\hline 13264 & 9 & $\mathbf{N w}-25$ & $13-12 N-13 W$ & Garfield, Newaygo \\
\hline$\ldots$ & 10 & Nw-W3 & $16-12 N-12 W$ & Brooks, Newaygo \\
\hline 13146 & 11 & Nw-29 & $33-13 N-11 W$ & Big Prairie, Newaygo \\
\hline 16245 & 12 & Mt-32 & $05-13 N-10 W$ & Aetna, Mecosta \\
\hline 16305 & 13 & Mt-3 & $03-13 N-10 W$ & Aetna, Mecosta \\
\hline 16005 & 14 & Mt-16 & $26-14 N-10 W$ & Mecosta, Mecosta \\
\hline 34622 & 15 & Mt-N3 & 04-14N-09W & Austin, Mecosta \\
\hline 11775 & 16 & Mt-5 & $23-15 N-09 W$ & Colfax, Mecosta \\
\hline 9806 & 17 & Mt-11 & $17-15 N-08 w$ & Martiny, Mecosta \\
\hline 12018 & 19 & Mt-22 & $12-16 N-08 W$ & Chippewa, Mecosta \\
\hline 11061 & 20 & Mt-28 & $12-16 N-08 W$ & Chippewa, Mecosta \\
\hline 16335 & 21 & Os-6 & $34-17 N-07 W$ & Orient, Osceola \\
\hline 12868 & 22 & $\mathrm{Cl}-13$ & $22-17 N-06 W$ & Garfield, Clare \\
\hline 10498 & 23 & $\mathrm{Cl}-10$ & $06-17 \mathrm{~N}-05 \mathrm{~W}$ & Surrey, Clare \\
\hline 31670 & 24 & Cl-N5 & $21-18 N-05 W$ & Lincoln, Clare \\
\hline 10795 & 25 & $\mathrm{Cl}-18$ & $12-18 N-05 W$ & Lincoln, Clare \\
\hline 11946 & 26 & $\mathrm{Cl}-20$ & $06-18 N-04 W$ & Hatton, Clare \\
\hline 14759 & 27 & $\mathrm{Cl}-17$ & $36-20 N-04 W$ & Frost, Clare \\
\hline 15433 & 28 & $\mathrm{Cl}-3$ & $19-20 N-03 W$ & Franklin, Clare \\
\hline 16985 & 29 & Rc-9 & $29-21 N-03 W$ & Roscommon, Roscommon \\
\hline 15702 & 30 & Rc-2 & $20-21 N-03 W$ & Roscommon, Roscommon \\
\hline 39826 & 31 & Rc-g3 & $23-22 N-03 W$ & Denton, Roscommon \\
\hline 5521 & 32 & Rc-g64 & $06-22 \mathrm{~N}-02 \mathrm{~W}$ & Bachus, Roscommon \\
\hline 16683 & 33 & Rc-g8 & $21-24 N-02 W$ & Higgins, Roscommon \\
\hline- & 34 & Rc-g7 & $02-24 N-02 W$ & Higgins, Roscommon \\
\hline 7864 & 35 & Rc-g17 & $36-23 N-01 W$ & Richfield, Roscommon \\
\hline- & 36 & R5 & $12-25 N-02 W$ & South Branch, Crawford \\
\hline
\end{tabular}


Table A2. Identification of geophysical and geologic logs used in the construction of hydrogeologic section B-B', Wexford County to Shiawassee County, Michigan

[Permit numbers are assigned to oil and gas wells by Michigan Department of Natural Resources; dashes indicate that no permit number was issued or that well was used for purposes other than oil or gas exploration or production. U.S. Geological Survey (USGS) identifiers are numbers assigned to logs on file at USGS, indicating county where well is located, type of well, and type of log]

\begin{tabular}{|c|c|c|c|c|}
\hline $\begin{array}{l}\text { Permit } \\
\text { number }\end{array}$ & $\begin{array}{l}\text { Number on } \\
\text { geologic } \\
\text { section }\end{array}$ & $\begin{array}{c}\text { USGS } \\
\text { identifier }\end{array}$ & $\begin{array}{c}\text { Section } \\
\text { Township } \\
\text { Range }\end{array}$ & Township name, county \\
\hline 29755 & 1 & Wx-g20 & $16-24 N-11 W$ & Hanover, Wexford \\
\hline 10303 & 2 & $\mathbf{W x}-3$ & $11-23 N-11 W$ & Antioch, Wexford \\
\hline 35866 & 3 & Wx-N1 & $05-23 N-10 W$ & Colfax, Wexford \\
\hline 12304 & 4 & $\mathbf{W x}-4$ & $11-22 N-10 W$ & Selma, Wexford \\
\hline 10661 & 5 & Wx-g58 & $24-22 \mathrm{~N}-10 \mathrm{~W}$ & Selma, Wexford \\
\hline 18209 & 6 & $W x-6$ & $36-22 N-10 W$ & Selma, Wexford \\
\hline 20742 & 7 & $W x-5$ & $13-21 N-10 W$ & Cherry Grove, Wexford \\
\hline 10754 & 8 & Os-8 & $09-20 \mathrm{~N}-09 \mathrm{~W}$ & Sherman, Osceola \\
\hline 25007 & 9 & Os-g15 & $14-20 \mathrm{~N}-09 \mathrm{~W}$ & Sherman, Osceola \\
\hline 15934 & 10 & Os-9 & $19-20 \mathrm{~N}-08 \mathrm{~W}$ & Highland, Osceola \\
\hline- & 11 & Os-24 & $34-20 \mathrm{~N}-09 \mathrm{~W}$ & Sherman, Osceola \\
\hline 14591 & 12 & Os-31 & $29-20 N-08 W$ & Highland, Osceola \\
\hline 11670 & 13 & Os-1 & $19-19 N-08 W$ & Hartwick, Osceola \\
\hline 9039 & 14 & Os-g97 & $25-19 N-08 W$ & Hartwick, Osceola \\
\hline 8573 & 15 & Os-g65 & $07-18 N-07 W$ & Sylvan, Osceola \\
\hline 14639 & 16 & Os-4 & $09-18 N-07 W$ & Sylvan, Osceola \\
\hline 32394 & 17 & Os-N1 & $03-17 N-07 W$ & Orient, Osceola \\
\hline 13739 & 18 & Os-12 & $03-17 N-07 W$ & Orient, Osceola \\
\hline 12375 & 19 & Os-29 & $12-17 N-07 W$ & Orient, Osceola \\
\hline 26256 & 20 & $\mathrm{Ib}-\mathrm{g} 45$ & $10-16 N-06 W$ & Coldwater, Isabella \\
\hline 12911 & 21 & $\mathrm{Ib}-65$ & $20-16 \mathrm{~N}-06 \mathrm{~W}$ & Coldwater, Isabella \\
\hline 11747 & 22 & Ib-13 & $02-15 N-06 W$ & Sherman, Isabella \\
\hline 18330 & 23 & Ib-57 & $13-15 N-06 \mathrm{~W}$ & Sherman, Isabella \\
\hline 23980 & 24 & Ib-L1 & $16-14 \mathrm{~N}-05 \mathrm{~W}$ & Deerfield, Isabella \\
\hline 15597 & 25 & $\mathrm{Ib}-6$ & $01-14 N-05 W$ & Deerfield, Isabella \\
\hline 16275 & 26 & Ib-7 & $17-14 N-04 W$ & Union, Isabella \\
\hline - & 27 & Ib-W2 & $27-14 N-04 W$ & Union, Isabella \\
\hline 16791 & 28 & $\mathrm{Ib}-10$ & 28-13N-04W & Lincoln, Isabella \\
\hline 9464 & 29 & Gr-g23 & $13-12 N-04 W$ & Seville, Gratiot \\
\hline - & 30 & Gr-W11 & $30-11 N-02 W$ & Emerson, Gratiot \\
\hline 10536 & 31 & Gr-3 & $36-11 N-03 W$ & Arcada, Gratiot \\
\hline 14844 & 32 & Gr-2 & $26-10 N-03 W$ & Newark, Gratiot \\
\hline 13920 & 33 & Gr-1 & $36-10 N-03 W$ & Newark, Gratiot \\
\hline 33991 & 34 & Gr-NFD-1 & $28-10 \mathrm{~N}-02 \mathrm{~W}$ & North Star, Gratiot \\
\hline 33382 & 35 & Gr-NFD-4 & $22-09 \mathrm{~N}-02 \mathrm{~W}$ & Washington, Gratiot \\
\hline 3703 & 36 & Gr-g79 & $36-10 N-01 W$ & Hamilton, Gratiot \\
\hline 33313 & 37 & Ct-N2 & $24-08 \mathrm{~N}-02 \mathrm{~W}$ & Greenbush, Clinton \\
\hline 33321 & 38 & Ct-N1 & $09-07 N-01 W$ & Ovid, Clinton \\
\hline 3586 & 39 & Ct-g21 & $25-07 N-01 W$ & Ovid, Clinton \\
\hline 1198 & 40 & Sw-g2 & $01-05 N-01 E$ & Woodhull, Shiawassee \\
\hline 23376 & 41 & Sw-g9 & $25-05 N-02 E$ & Perry, Shiawassee \\
\hline
\end{tabular}




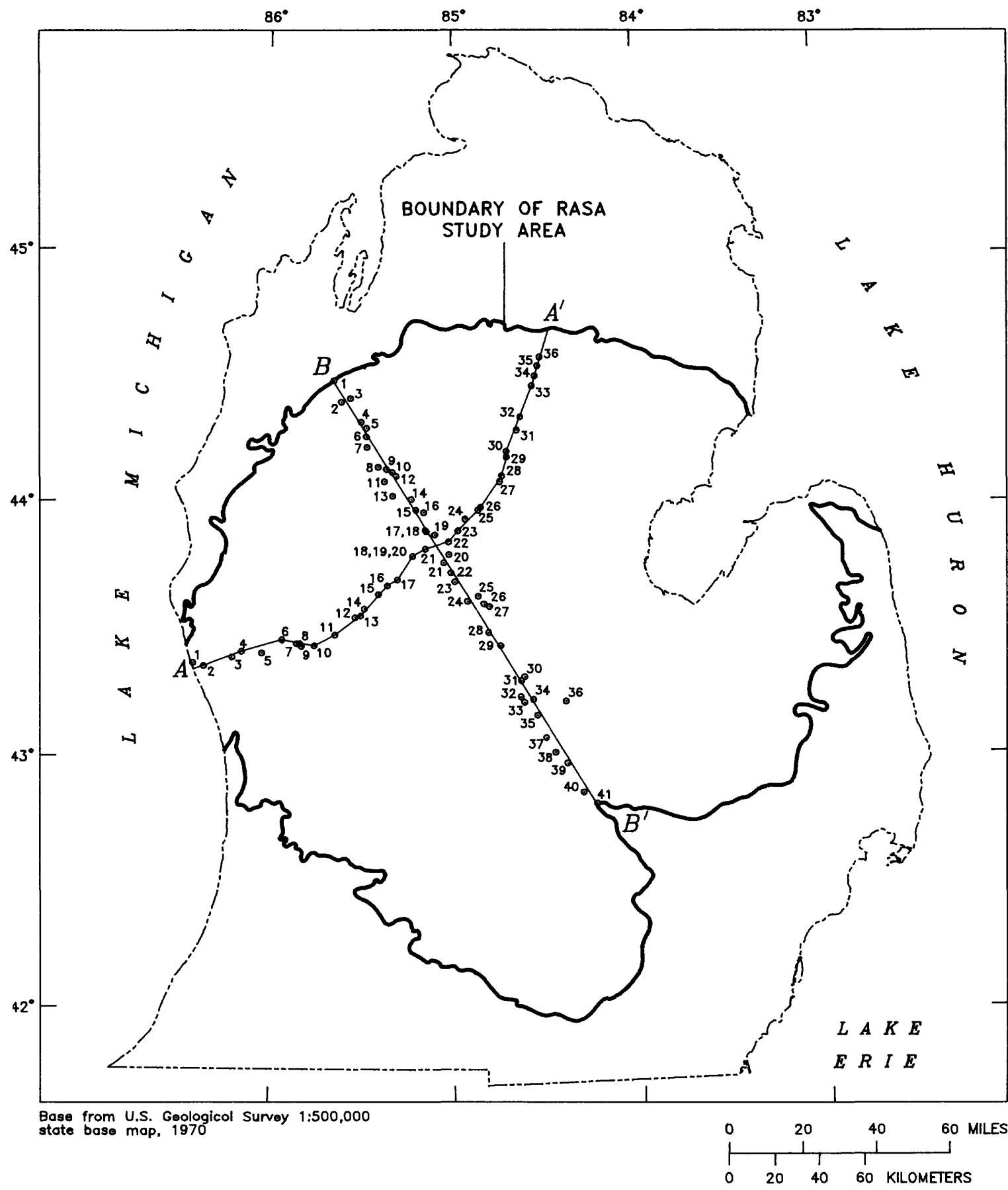

EXPLANATION

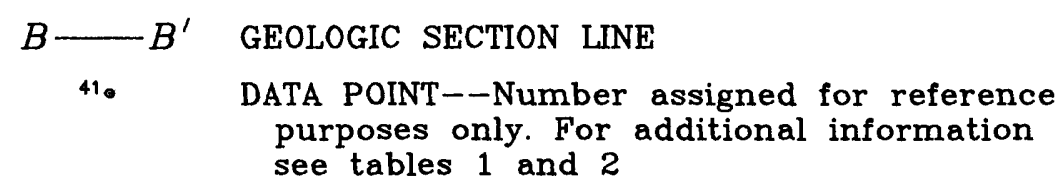

Figure A1. Location of geophysical and geologic logs used in the construction of hydrogeologic sections A-A' and B-B', central Lower Peninsula of Michigan. 

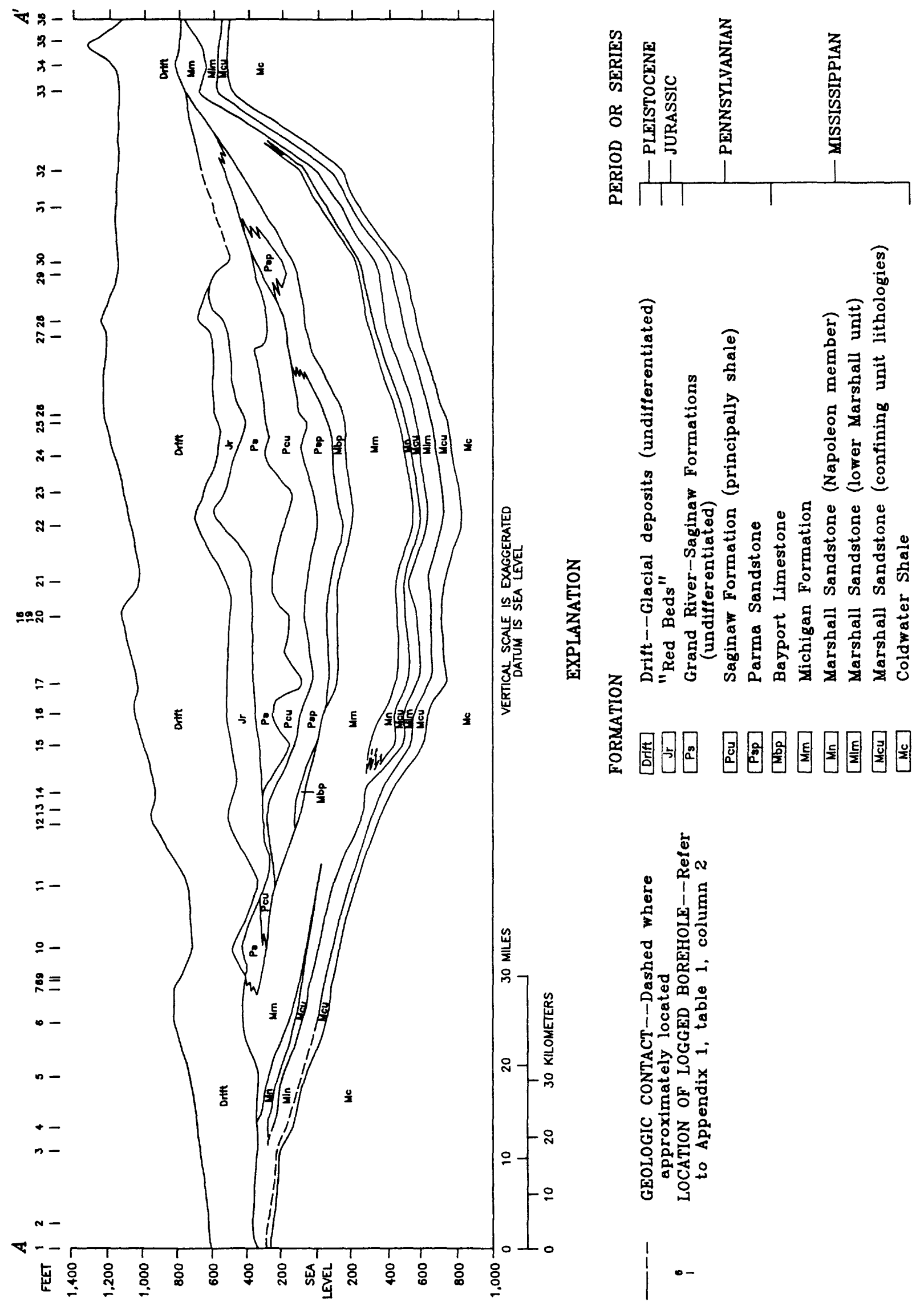

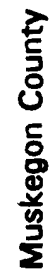

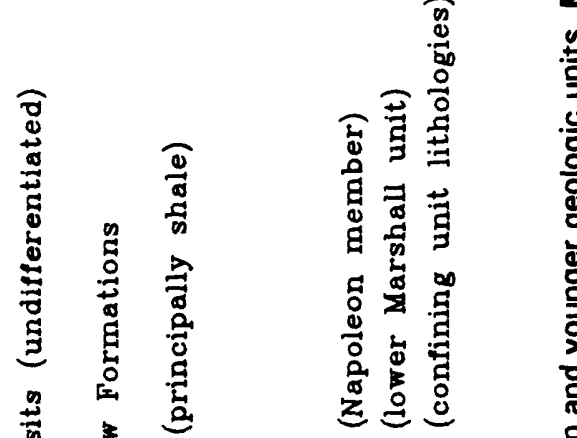

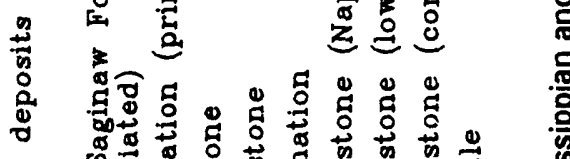
Ф ठี ๓

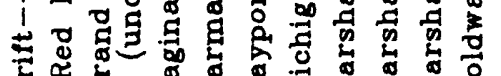
意周日月圆圆圆国国国国 $\frac{0}{\frac{2}{0}}$ 要范

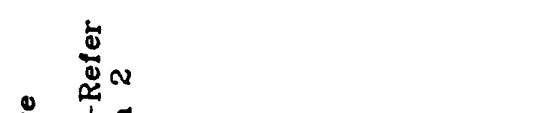

. 옹 究 $<\frac{5}{4}$ $<$ 돈

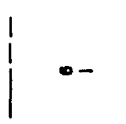




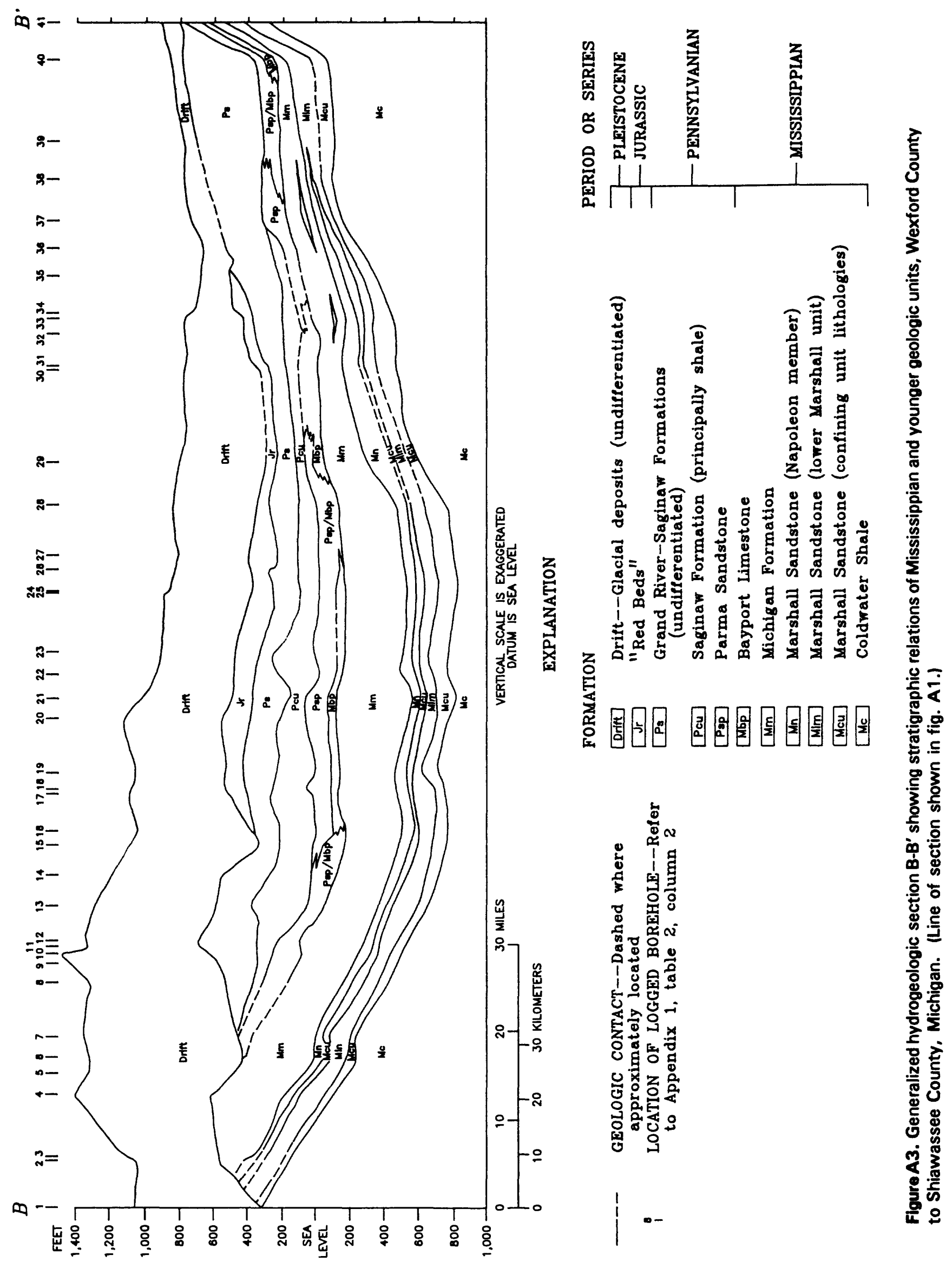





\section{APPENDIX B. INTERPRETATION OF GEOPHYSICAL AND GEOLOGIC LOGS}

\section{CONTENTS}

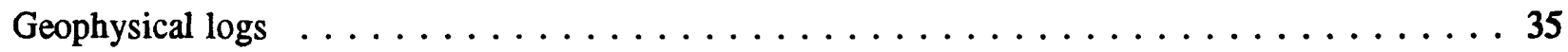

Geologic logs 35

Figure B1. Sample suite of geophysical logs showing typical electric-log, gamma-ray log, and porosity-log traces of selected Mississippian rock units in the central Lower Peninsula of Michigan 



\section{GEOPHYSICAL LOGS}

Production of oil and gas in the Michigan Basin began in 1925 (Dorr and Eschman, 1970, p. 237), and Michigan continues to be a major producer of hydrocarbons. Geophysical logging of hydrocarbon-exploration boreholes became common practice in the 1940's. RASA investigators located approximately 300 electricalresistivity/spontaneous-potential logs (or old electric logs; Hilchie, 1979) of boreholes drilled before 1953, which were run in shallow-cased boreholes that were open to Pennsylvanian and Mississippian rocks. At many places, the logged boreholes were open to Pleistocene glacial deposits, which allows for characterization of geophysical properties of all units in the aquifer system. Discoveries of natural gas in Mississippian sandstones in the late 1950's resulted in continued exploration activity; most boreholes drilled after 1960 have been logged with a suite of improved geophysical-logging tools, including caliper, gamma-ray, dual-induction or dual-laterolog, neutron-porosity, and density-porosity equipment. Westjohn $(1989,1994 \mathrm{~b})$ included detailed discussion of applications of geophysical logs in the characterization of hydrostratigraphic units in the Michigan Basin regional aquifer system study area. Aquifers and confining units have distinct geophysical-log traces, as can be seen in figure B1.

Permeable lithologies can be identified from traces on electrical-resistivity-log, due in part to the common use of high-density muds (densities greater than 9 grams per cubic centimeter) during drilling of oil and gas wells. Filtrate from heavy drilling mud typically displaces native pore fluid in permeable formations. The effects of infiltration of fluids from drilling mud can be measured with electrical-resistivity-logging tools. A common design of logging tools involves multiple electrode configurations that allow measurement of electrical resistivity at three lateral distances from the borehole opening. One configuration of electrodes is designed to measure electrical resistivity very near the borehole, in the flushed zone (area of total displacement of formation fluid by mud filtrate; Hearst and Nelson, 1985, p. 28-30). A second configuration measures electrical resistivity in the transition zone (area of mixing of formation fluid and mud filtrate), and a third configuration measures electrical resistivity in the noninvaded zone (true formation resistivity). In boreholes where formation fluid and mud filtrate have substantially different electrical resistivities (which is the general case in Michigan) and drilling fluid has invaded permeable strata, a separation of electrical-resistivity-log traces is observed. The separations of electrical-resistivity-log traces commonly observed in aquifers of the study area are illustrated by the example $\log$ (fig. B1). The amount of separation of the three traces recorded on electrical-resistivity logs is a function of formation permeability and the distance that fluid has infiltrated the formation, as well as the amount of contrast in electrical resistivity between formation fluid and mud filtrate.

Electric logs and combination geophysical-log suites (gamma ray, neutron porosity, density porosity, and dual resistivity) are available for much of the study area from the Oil and Gas Division, Michigan Geological Survey. Geophysical logs are numerous for some areas of the basin where discovery wells or indications of oil and gas stimulated exploration activities. Exploration boreholes in areas surrounding oil- and gas-discovery wells also were commonly logged.

Geophysical logs are sparse or nonexistent for most of the Thumb Area (fig. 1) and the southern part of the study area, with the exception of a few gamma-ray logs that were run in cased boreholes.

\section{GEOLOGIC LOGS}

Geologic logs of oil, gas, and water wells are on file with the Michigan Geological Survey and the Michigan Department of Public Health. Geologic descriptions recorded on logs of oil, gas, and water wells (lithologic data, formation tops, and so forth) were used to map aquifer- and confining-unit boundaries in parts of the study area for which geophysical logs are sparse or unavailable. 


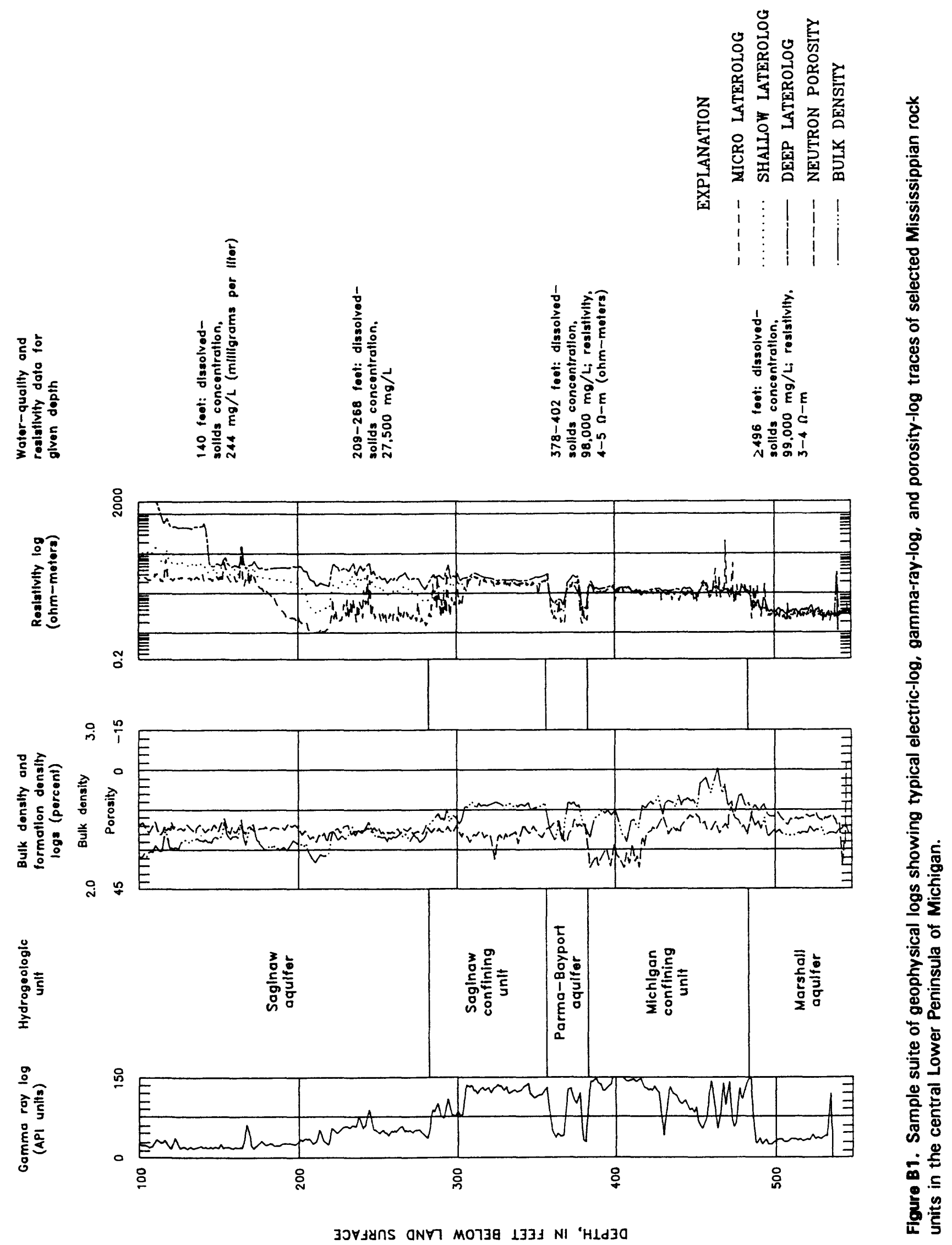




\section{APPENDIX C. LOCATIONS OF BOREHOLES AND LOGS}

\section{CONTENTS}

Figures C1. Locations of boreholes and logs used to construct surface-configuration and thickness maps of Michigan confining unit, central Lower Peninsula of Michigan . 39

C2. Locations of boreholes and logs used to construct surface-configuration map of the Marshall aquifer, central Lower Peninsula of Michigan . . . . . . . 40

C3. Locations of boreholes and geophysical logs used to construct thickness map of Marshall aquifer, central Lower Peninsula of Michigan ...........41

C4. Locations of boreholes and logs used to construct surface-configuration map of Coldwater confining unit, central Lower Peninsula of Michigan . . 



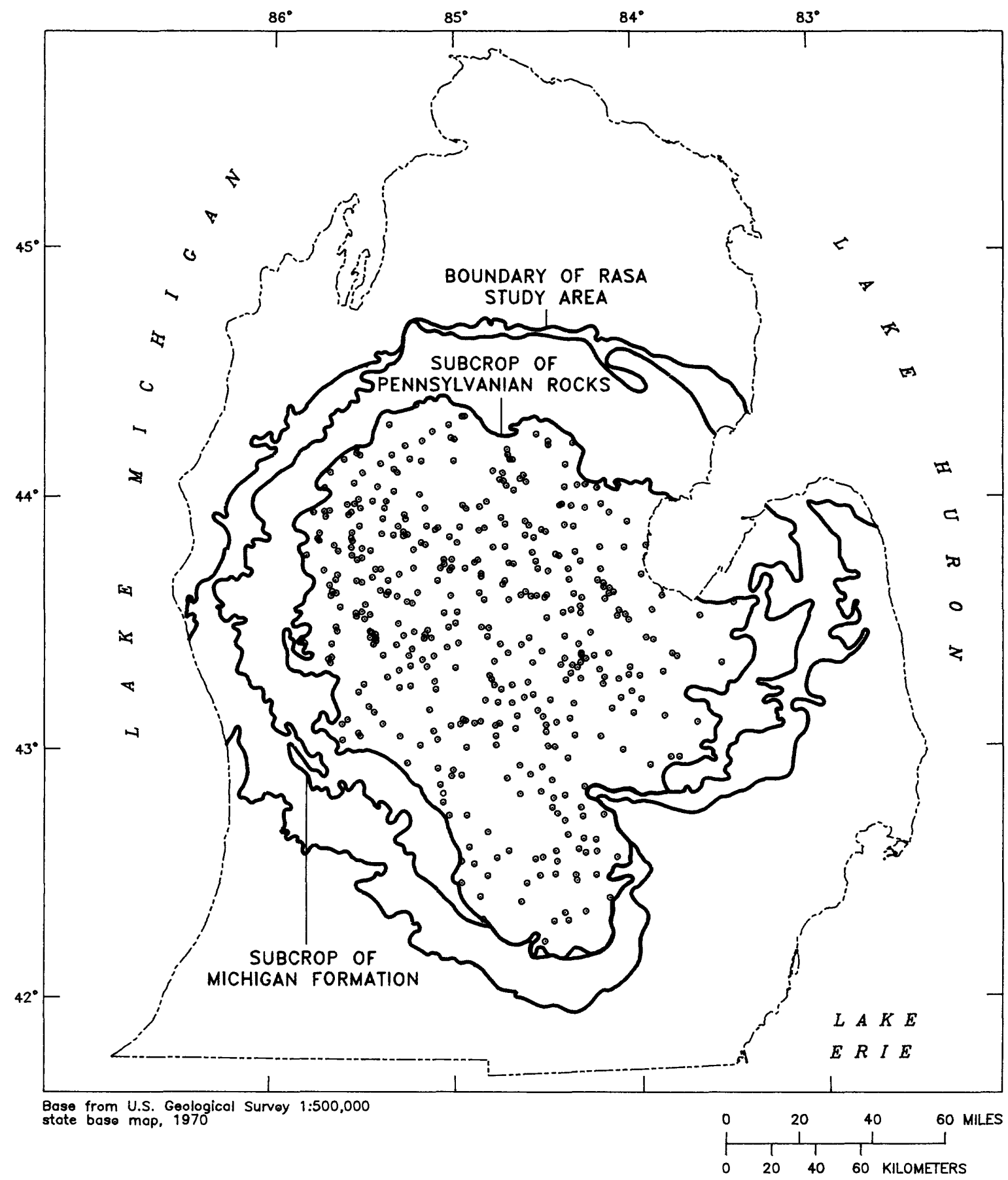

EXPLANATION

- DATA POINT--Shows location of boreholes and logs used to construct figure 4 and 5

Figure C1. Locations of boreholes and logs used to construct surface-configuration and thickness maps of Michigan confining unit, central Lower Peninsula of Michigan. 


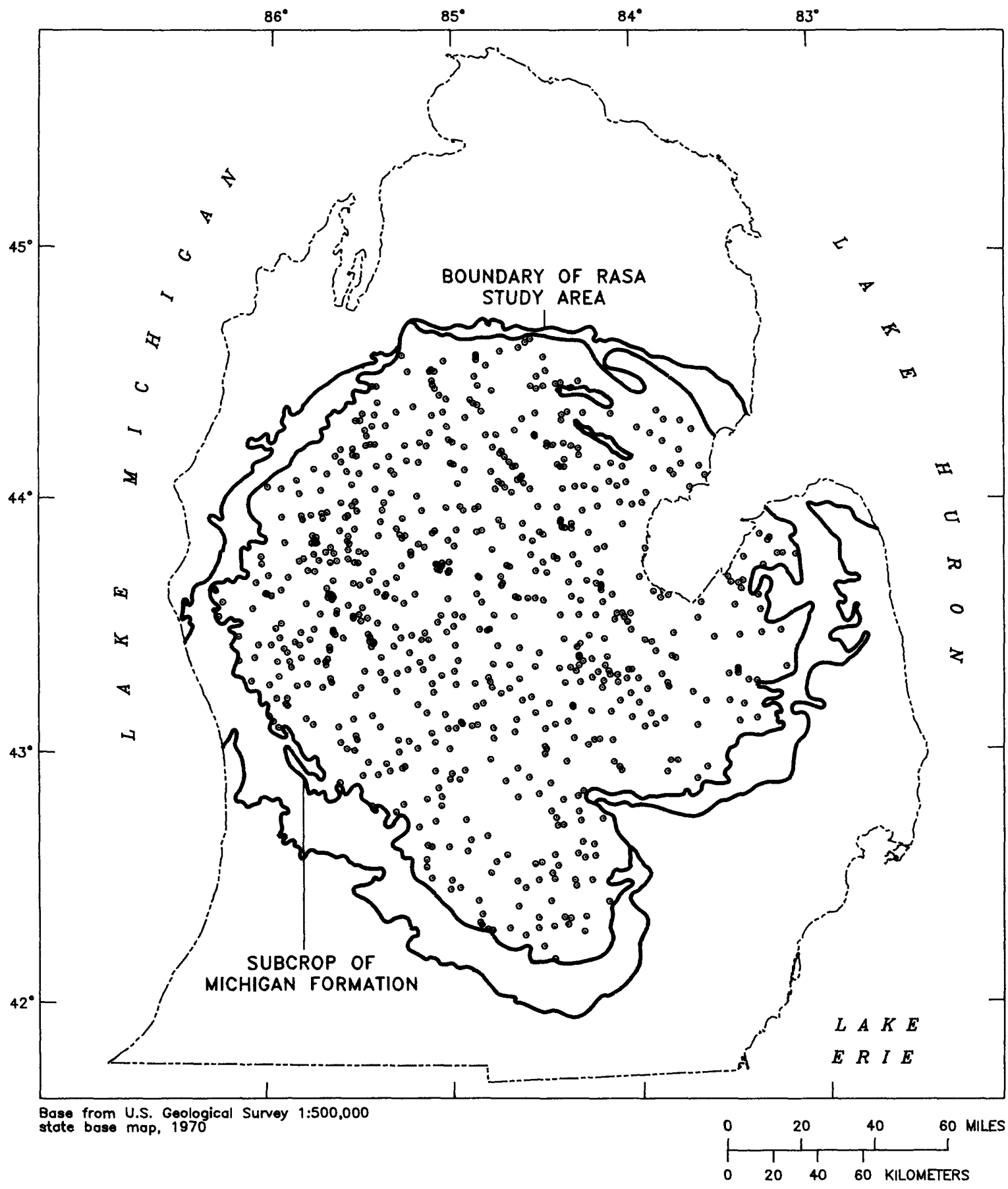

EXPLANATION

- DATA POINT--Shows location of boreholes and logs used to construct figure 6 and 7

Figure C2. Locations of boreholes and logs used to construct surface-configuration map of Marshall aquifer, central Lower Peninsula of Michigan. 


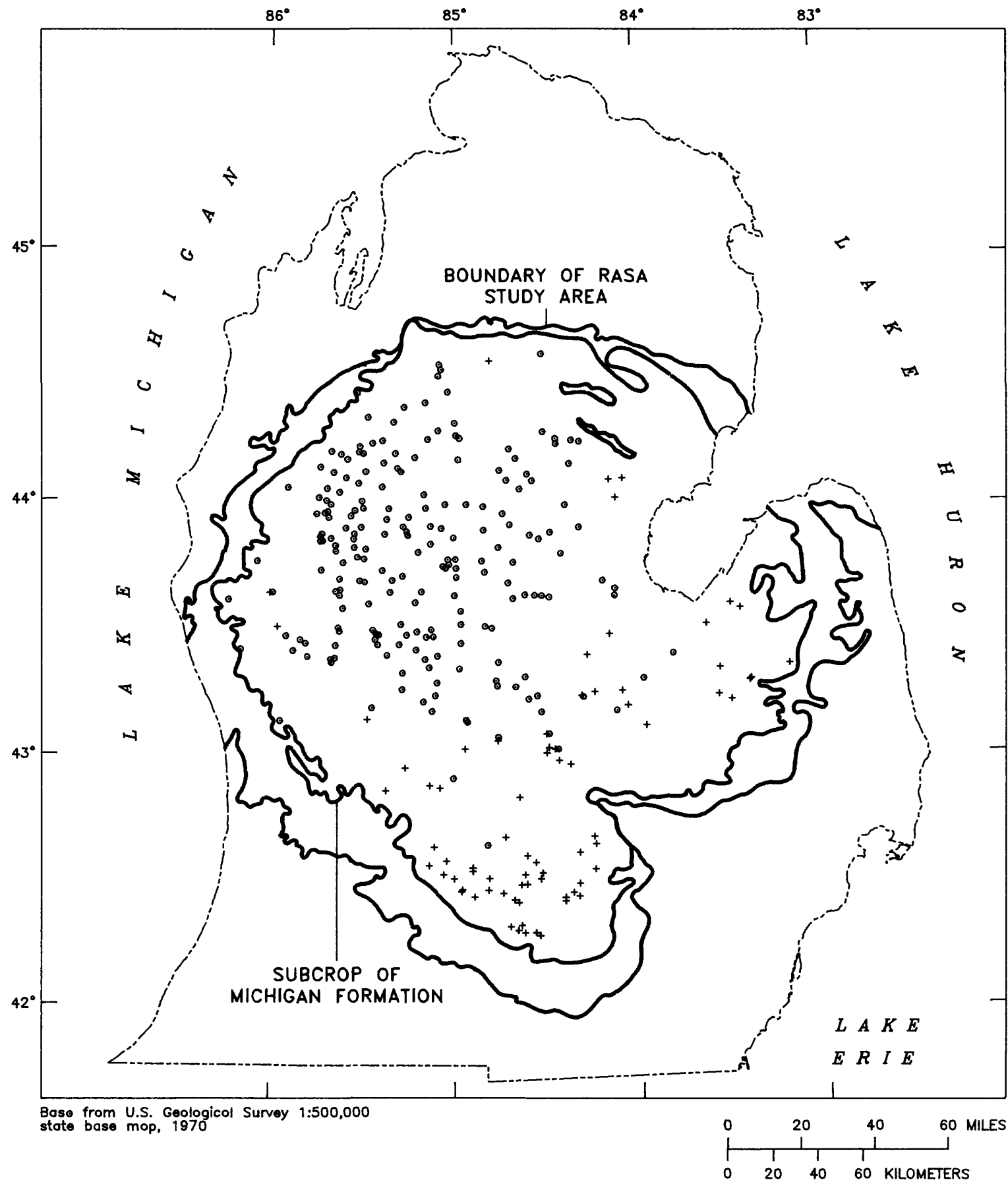

EXPLANATION

DATA POINT--Shows location of boreholes and type of $\log$ interpreted in construction of figure 7

- Resistivity log

+ Gamma-ray log

Figure C3. Locations of boreholes and geophysical logs used to construct thickness map of Marshall aquifer, central Lower Peninsula of Michigan. 


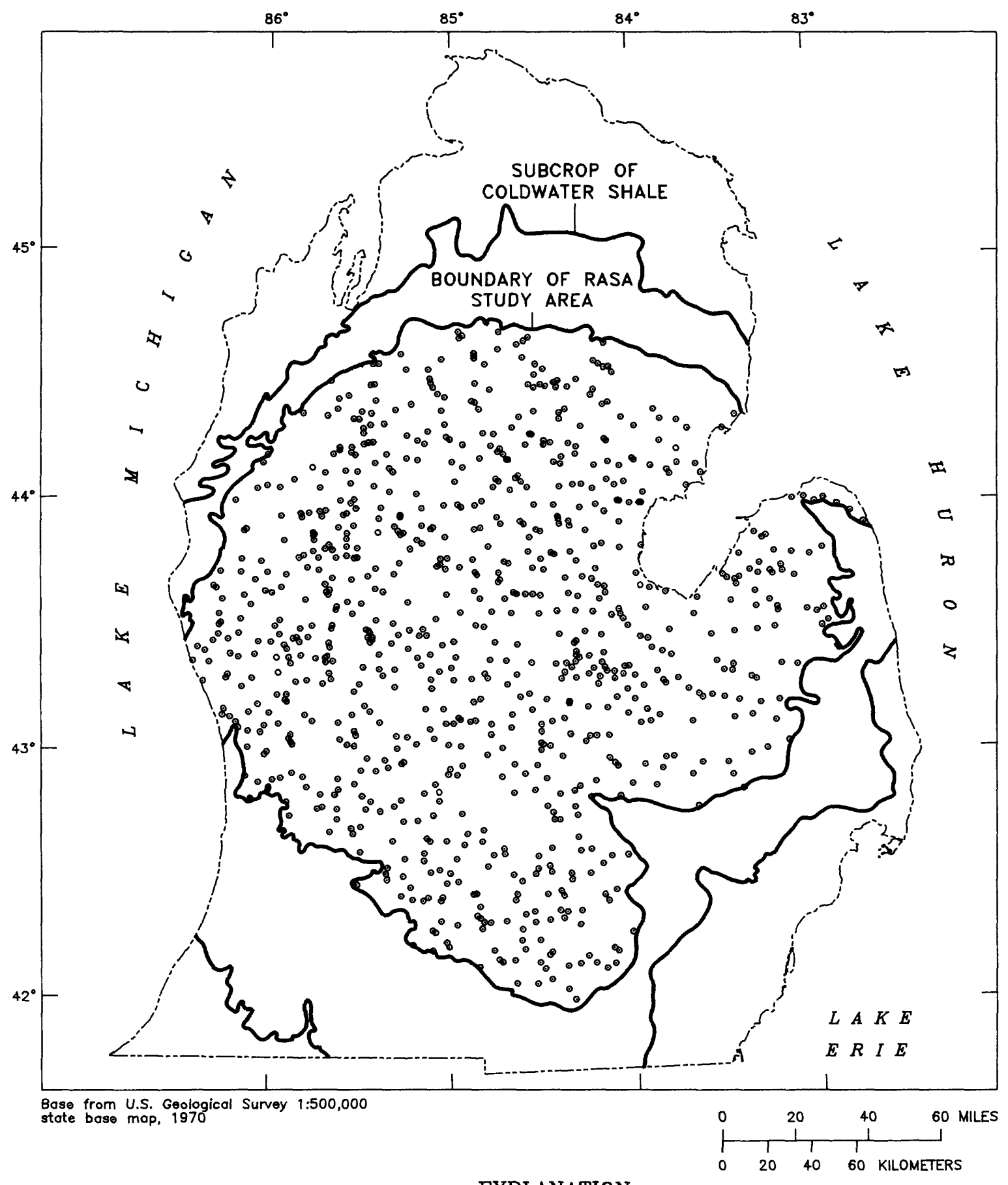

EXPLANATION

- DATA POINT--Shows location of boreholes and logs used to construct figure 8

Figure C4. Locations of boreholes and logs used to construct surface-configuration map of Coldwater confining unit, central Lower Peninsula of Michigan. 


\section{APPENDIX D. HYDRAULIC PROPERTIES OF MISSISSIPPIAN SANDSTONES}

\section{CONTENTS}

Table D1. Range of porosities and vertical hydraulic conductivities measured of 43 Mississippian sandstone core specimens $\ldots \ldots \ldots \ldots \ldots \ldots \ldots$

Table D2. Range of porosities and horizontal hydraulic conductivities measured of 20 Mississippian sandstone core specimens

Figure D1. Porosities and vertical hydraulic conductivities measured of Mississippian sandstone core specimens from the central Lower Peninsula of Michigan . . . . . . 46

Figure D2. Porosities and horizontal hydraulic conductivities measured of Mississippian sandstone core specimens from the central Lower Peninsula of Michigan 

Table D1. Range of porosities and vertical hydraulic conductivities measured of $\mathbf{4 3}$ Mississippian sandstone core specimens

[Sandstone cores are from the lower Marshall sandstone or Napoleon Sandstone (member of Marshall Sandstone); these units form the Marshall aquifer. Micaceous sandstones/siltstones form part of the Marshall sedimentary sequence, and because of low hydraulic conductivities, are not included in thickness map of the Marshall aquifer. See fig. D1, a plot of all porosity and vertical-hydraulicconductivity data. Abbreviations: $\mathrm{Kv}$, vertical hydraulic conductivity; $\mathrm{ft} / \mathrm{d}$, feet per day]

\begin{tabular}{cccc}
\hline $\begin{array}{c}\text { Sample type } \\
\text { (no. of } \\
\text { samples) }\end{array}$ & $\begin{array}{c}\text { Porosity range } \\
\text { (percent) }\end{array}$ & $\begin{array}{c}\text { Kv (ft/d) } \\
\text { (minimum) }\end{array}$ & $\begin{array}{c}\text { Kv (ft/d) } \\
\text { (maximum) }\end{array}$ \\
\hline $\begin{array}{c}\text { Sandstone } \\
(28)\end{array}$ & $16-25$ & $3.4 \times 10^{-4}$ & $1.3 \times 10^{0}$ \\
$\begin{array}{c}\text { Micaceous } \\
\text { sandstone/ } \\
\text { siltstone } \\
(15)\end{array}$ & $15-23$ & $8.5 \times 10^{-6}$ & $6.0 \times 10^{-3}$ \\
\hline
\end{tabular}

Table D2. Range of porosities and horizontal hydraulic conductivities measured of 20 Mississippian sandstone core specimens

[Sandstone core samples are from the lower Marshall sandstone or Napoleon Sandstone (member of the Marshall Sandstone); these units form the Marshall aquifer. Micaceous sandstones/siltstones form the basal part of the Marshall sedimentary sequence, and because of low hydraulic conductivities, are not included in thickness map of the Marshall aquifer. See fig. D2, a plot of all porosity and horizontalhydraulic-conductivity data. Abbreviations: $\mathrm{Kh}$, horizontal hydraulic conductivity; $\mathrm{ft} / \mathrm{d}$, feet per day]

\begin{tabular}{cccc}
\hline $\begin{array}{c}\text { Sample type } \\
\text { (no. of } \\
\text { samples) }\end{array}$ & $\begin{array}{c}\text { Porosity range } \\
\text { (percent) }\end{array}$ & $\begin{array}{c}\text { Kv (ft/d) } \\
\text { (minimum) }\end{array}$ & $\begin{array}{c}\text { Kv (ft/d) } \\
\text { (maximum) }\end{array}$ \\
\hline $\begin{array}{c}\text { Sandstone } \\
(10)\end{array}$ & $17-25$ & $7.0 \times 10^{-3}$ & $1.8 \times 10^{0}$ \\
$\begin{array}{c}\text { Micaceous } \\
\text { sandstone/ } \\
\text { siltstone } \\
(10)\end{array}$ & $11-21$ & $8.9 \times 10^{-6}$ & $2.5 \times 10^{-3}$ \\
\hline
\end{tabular}




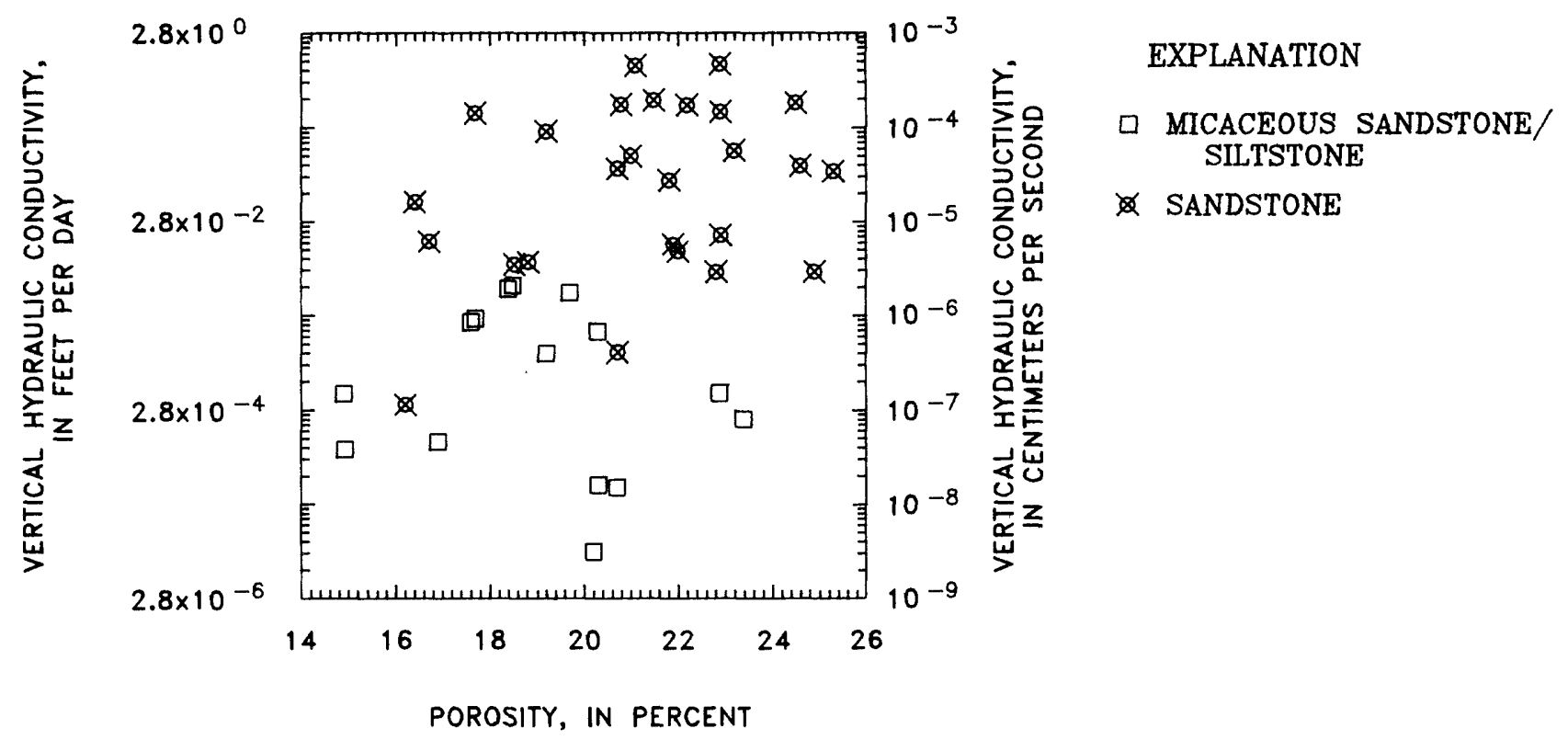

Figure D1. Porosities and vertical hydraulic conductivities measured of Mississippian sandstone core specimens from the central Lower Peninsula of Michigan.

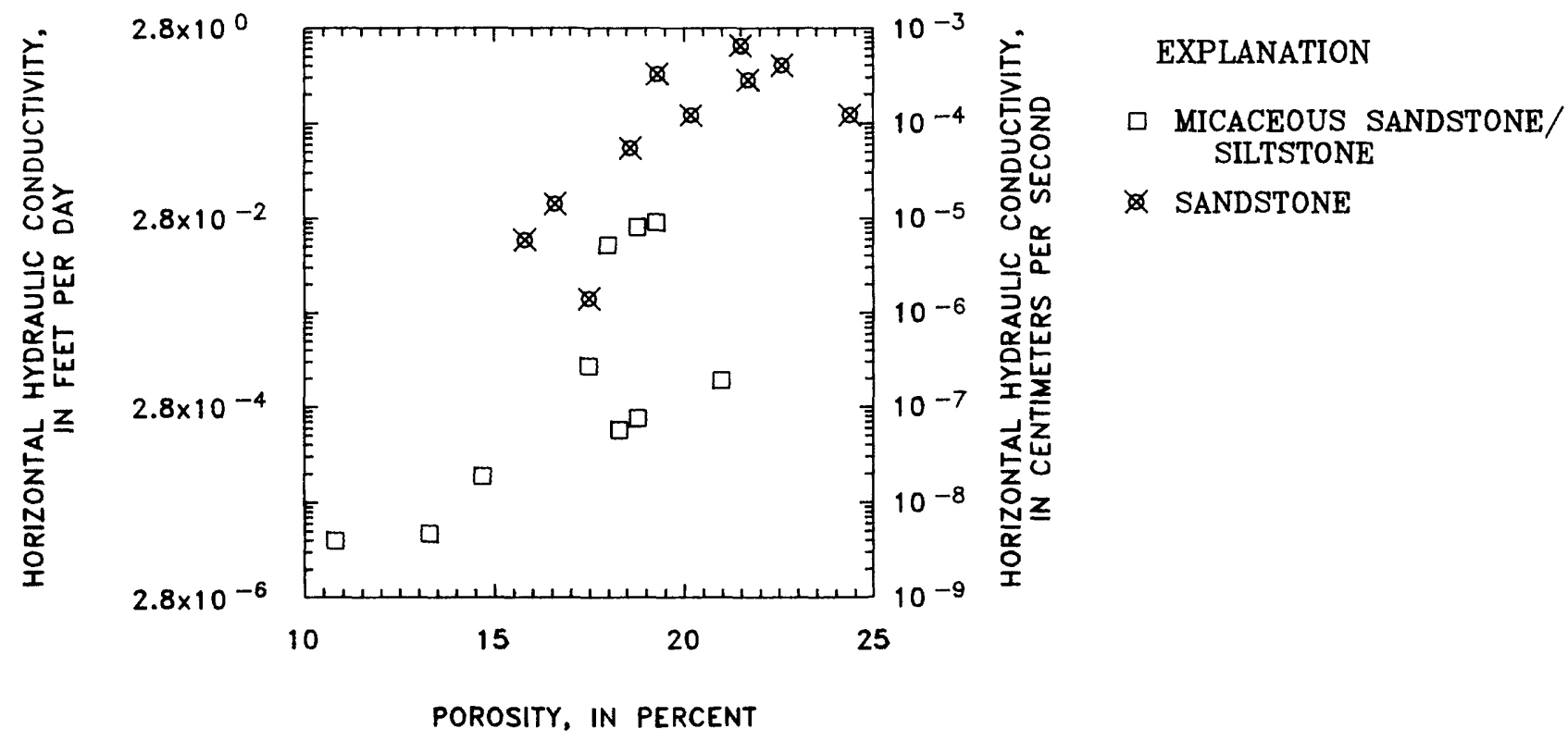

Figure D2. Porosities and horizontal hydraulic conductivities measured of Mississippian sandstone core specimens from the central Lower Peninsula of Michigan. 